OPEN ACCESS

Edited by:

Jordi Riba

Sant Pau Institute for Biomedical

Research, Spain

Reviewed by:

Esther Melamed,

University of Texas at Austin,

United States

Mark Ware

McGill University, Canada

${ }^{*}$ Correspondence:

José A. Crippa

jcrippa@fmrp.usp.br

Specialty section:

This article was submitted to

Multiple Sclerosis and

Neuroimmunology,

a section of the journal

Frontiers in Immunology

Received: 09 October 2017

Accepted: 14 August 2018

Published: 21 September 2018

Citation:

Crippa JA, Guimarães FS,

Campos AC and Zuardi AW (2018)

Translational Investigation of the Therapeutic Potential of Cannabidiol

(CBD): Toward a New Age.

Front. Immunol. 9:2009.

doi: 10.3389/fimmu.2018.02009

\section{Translational Investigation of the Therapeutic Potential of Cannabidiol (CBD): Toward a New Age}

\author{
José A. Crippa ${ }^{1,2 \star}$, Francisco S. Guimarães ${ }^{2,3}$, Alline C. Campos ${ }^{2,3}$ and Antonio W. Zuardi ${ }^{1,2}$ \\ ${ }^{1}$ Department of Neurosciences and Behavior, Faculty of Medicine of Ribeirão Preto, University of São Paulo, São Paulo, \\ Brazil, ${ }^{2}$ National Institute for Translational Medicine (INCT-TM; CNPq), São Paulo, Brazil, ${ }^{3}$ Department of Pharmacology, \\ Faculty of Medicine of Ribeirão Preto, University of São Paulo, São Paulo, Brazil
}

Background: Among the many cannabinoids in the cannabis plant, cannabidiol (CBD) is a compound that does not produce the typical subjective effects of marijuana.

Objectives: The aim of the present review is to describe the main advances in the development of the experimental and clinical use of cannabidiol CBD in neuropsychiatry.

Methods: A non-systematic search was performed for studies dealing with therapeutic applications of $\mathrm{CBD}$, especially performed by Brazilian researchers.

Results: CBD was shown to have anxiolytic, antipsychotic and neuroprotective properties. In addition, basic and clinical investigations on the effects of CBD have been carried out in the context of many other health conditions, including its potential use in epilepsy, substance abuse and dependence, schizophrenia, social phobia, posttraumatic stress, depression, bipolar disorder, sleep disorders, and Parkinson.

Discussion: CBD is an useful and promising molecule that may help patients with a number of clinical conditions. Controlled clinical trials with different neuropsychiatric populations that are currently under investigation should bring important answers in the near future and support the translation of research findings to clinical settings.

Keywords: cannabidiol, CBD, Cannabis sativa, anxiolytic, antiepileptic, neuroprotection

\section{INTRODUCTION}

The plant Cannabis sativa (cannabis) contains more than 100 chemical compounds that share a similar chemical structure, known as cannabinoids. The main psychoactive compound in cannabis is $\Delta$-9-tetrahydrocannabinol ( $\triangle 9$-THC), responsible for the main effects associated with the use of the plant. Among the many cannabinoids in the plant, our group has focused on CBD, a compound that does not produce the typical subjective effects of marijuana (1).

Since the 1970s, our group has published a number of scientific articles showing the potential therapeutic effects of CBD in different animal models of neuropsychiatric disorders, as well as in clinical trials with humans. We were the first to demonstrate the anxiolytic and antipsychotic effects of CBD in animals, in the 1970s and 1980s, and later in humans, with rather promising results (2). In addition to anxiety and psychosis, basic and clinical research on other therapeutic possibilities of CBD was conducted. Moreover, patentable synthetic analogs of CBD with strong potential for knowledge transfer to the productive sector have recently been developed to offer the possibility of benefits for patients with many health conditions (3). 
The aim of the present review is to report the main contributions for the development of the therapeutical potential of CBD in neuropsychiatry, especially performed by Brazilian researchers, which helped to transform the view of $\mathrm{CBD}$ from an inactive cannabinoid to a medicine with multiple actions. The studies included here were selected based on searches performed in the online databases PubMed, Web of Science and ScieELO for papers dealing with the therapeutic applications of CBD ("cannabidiol" was used as a keyword).

\section{ANCIENT HISTORY: AN INACTIVE CANNABINOID (1940s-1960s)}

Cannabidiol was isolated from cannabis extracts by Adams et al. (4). However, no further investigation was carried out for almost 25 years, except for a few studies about its isolation. The exact chemical structure of CBD (Figure 1) was elucidated only in 1963 by the group of Professor Raphael Mechoulam, from the Hebrew University of Jerusalem in Israel (6). Throughout the 1960s, the same group was responsible for the determination of the precise structure and stereochemistry of $\triangle 9$-THC (Figure 1) and other major cannabinoids. These findings opened a new research field on the pharmacological activity of cannabis constituents. Before the 1970s, only a few pharmacological studies on CBD had been made, which concluded that CBD had no cannabis-like activity, as opposed to $\triangle 9$-THC (7).

\section{THE MIDDLE AGES: AN INACTIVE CANNABINOID THAT INTERACTS WITH $\triangle 9$-THC (1970s)}

In the early 1970s, several studies reported that CBD was not able to mimic the effects of marijuana, which led to the belief that it would be a non-active cannabinoid. However, this view began to change with the perception that the activity of different cannabis extracts varied widely and that this variation could not be attributed to different levels of $\triangle 9$-THC in the samples $(8,9)$. This finding led to the hypothesis that other cannabinoids in general, and CBD in particular, could interfere with the effects of $\triangle 9$-THC.

During this period, a Brazilian research group led by Professor Elisaldo Carlini gave important contributions to the field with their early investigations on the effects of CBD, $\triangle 9$-THC, and other cannabinoids. In this context, the investigation of the interaction between the $\triangle 9$-THC and CBD began. These studies indicated that CBD had pharmacological effects of its own, which have been investigated since then and led to the current view that CBD actually has a broad spectrum of action (2).

The first study in this line of investigation compared street cannabis samples and a synthetic extract containing the same concentrations of $\triangle 9$-THC, CBN, and CBD (10). The authors found that the effects of the samples were not the same in the animals tested, consonant with earlier evidence that the effects of the plant were not only due to its $\triangle 9$-THC content $(9,11)$. Later studies on the interaction between cannabinoids showed that $\mathrm{CBD}$ both blocked and potentiated the effects of

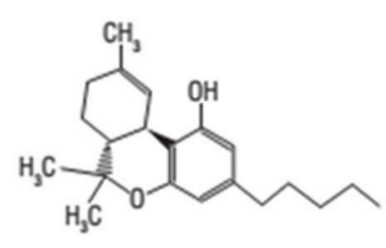

$\triangle 9-\mathrm{THC}$

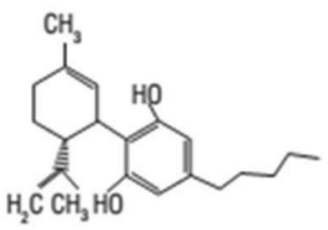

Cannabidiol
FIGURE 1 | Chemical structures of $\Delta 9$-tetrahydrocannabinol $(\Delta 9-\mathrm{THC})$ and cannabidiol (CBD) (5).

$\triangle 9$-THC in animal tests, depending on the ratio and dose relationship between the two cannabinoids $(12,13)$. Nowadays, we have evidence that the pharmacokinetic interaction that results in the blockade of $\mathrm{P}-450$ cytochromes by $\mathrm{CBD}$ and inhibits the metabolism of $\triangle 9$-THC can be overcome by a pharmacodynamic interaction, when the $\mathrm{CBD} / \Delta 9-\mathrm{THC}$ ratio is high and/or administration of the two cannabinoids occurs simultaneously or very close in time (14).

Studying the interaction between $\mathrm{CBD}$ and $\triangle 9$-THC in healthy humans, high oral doses of $\triangle 9$-THC provoked anxiety and psychotic symptoms, which were attenuated when CBD was administered together with $\triangle 9$-THC (15). These results contributed to support the association of the two cannabinoids in Sativex ${ }^{\circledR}$ (GW-Pharm, UK), a medication used in worldwide for the treatment of pain and spasticity in multiple sclerosis. In addition, these observations contributed to the understanding of the distinct effects of marijuana in different populations, explained by the varying concentrations of the plant's constituents. At the same time, the findings described here suggested that CBD could have anxiolytic and antipsychotic properties and gave rise to a line of research that continues to this day.

\section{MODERN HISTORY: CBD EFFECTS ON ANXIETY, DEPRESSION, AND PSYCHOSIS (1980s-1990s)}

After a boom in the 1970s, the number of studies on CBD over the two decades that followed became stable, indicating a fall in the interest for the study of the therapeutic actions of this cannabinoid. Although a few groups continued to provide sparse contributions on the subject, much of the production in the field was limited to investigations of the anxiolytic, antidepressant, and antipsychotic properties of CBD performed by Brazilian researchers.

\section{Anxiolytic Action Studies With Animal Models}

As mentioned above, early studies in rodents in the beginning of the 1980s indicated that CBD could interfere with the effects of $\triangle 9$-THC and, more specifically, that CBD attenuated the anxiogenic effects of THC on conditioned emotional responses $(16,17)$. In support to these findings, the same group 
found that $\mathrm{CBD}$ was capable to prevent the anxiogenic and psychosis-like effects induced by elevated doses of $\triangle 9$-THC (15). Even though the mechanisms of action of $\triangle 9$-THC and CBD were unknown at the time, Zuardi and colleagues had already shown that CBD could potentiate some neuroendocrine effects of $\triangle 9$-THC (13). This finding indicated that CBD was not a simple receptor antagonist of $\triangle 9$-THC. Together, these results suggested that CBD could be able to cause a physiological antagonism of $\triangle 9$-THC effects, having anxiolytic and antipsychotic properties. As shown later, these properties have been confirmed in both laboratory animals and humans.

Initial studies in this line yielded contradictory results. Whereas Zuardi and Karniol et al. (17) found that CBD $(10 \mathrm{mg} / \mathrm{kg})$ was able to attenuate conditioned emotional responses in rats, Silveira Filho and Tufik (18) failed to find any effects of CBD $(100 \mathrm{mg} / \mathrm{kg})$ in the Geller-Seifter conflict test, considered, at that time, the gold standard among the animal models of anxiety. These apparently contradictory results were explained by Guimarães et al. (19), using a recently introduced test that was sensitive to anxiolytic drugs, the elevated plus maze (EPM). Using this model and covering a full dose-response curve, they showed that in rats $\mathrm{CBD}$ does induce anxiolytic-like effects at lower doses $(2.5-10 \mathrm{mg} / \mathrm{kg})$ that completely disappear at higher doses (19). As discussed below, this bell-shaped dose-response curve was recently confirmed in humans tested in a clinical model of experimental anxiety.
Since this initial work, several studies have confirmed that CBD decreases anxiety in rodents after either single or repeated administration (Table $\mathbf{1}$ ).

The EPM test is based on innate fear of open and elevated spaces and has been usually associated with general anxiety in humans. Therefore, these investigations were expanded on the effects of CBD to models associated with other anxietyrelated clinical disorders, such as panic, post-traumatic stress (PTSD), and obsessive-compulsive disorder (OCD; Table 1). It was also found that CBD has a clear anti-stress effect after either acute or repeated administration, attenuating the behavioral and autonomic consequences of acute restraint stress $(31,32)$ and the anxiogenic effects of chronic unpredictable stress [CUS-(28)]. These effects could be associated with the antidepressant-like effects of CBD observed in the forced swimming stress' $(33,34)$, Wistar-Kyoto (35) and bulbectomy models (36).

\section{Mechanisms and Possible Brain Sites of CBD's Anxiolytic and Antidepressant Effects}

CBD has a complex pharmacology, with several mechanisms proposed to explain its action. Most studies investigating CBD's mechanisms of action have been made in vitro (30), but for more than 10 years now, in vivo studies using animal models has been investigating how CBD produces its beneficial effects in neuropsychiatric disorders.

To discover the possible sites underlying CBD effects, a series of studies were performed in rodents using intracerebral drug administration into brain areas related to defensive

TABLE 1 | Preclinical studies: anxiolytic-like effects of cannabidiol after systemic administration in rodents.

\begin{tabular}{|c|c|c|c|c|}
\hline Animal model & $\begin{array}{l}\text { Proposed related } \\
\text { disorder }\end{array}$ & Species & CBD effects (dose range $\mathrm{mg} / \mathrm{kg}$ ) & References \\
\hline \multicolumn{5}{|c|}{ SINGLE ADMINISTRATION } \\
\hline $\begin{array}{l}\text { Elevated plus maze, } \\
\text { Vogel conflict test }\end{array}$ & Generalized anxiety & Rats & $\begin{array}{l}\text { Anxiolytic } \\
\text { (5-10 mg/kg, bell-shaped dose-response } \\
\text { curve) }\end{array}$ & $(19,20)$ \\
\hline Vogel conflict test & Generalized anxiety & Rats & $\begin{array}{l}\text { Anxiolytic } \\
(10 \mathrm{mg} / \mathrm{kg})\end{array}$ & $(21)$ \\
\hline $\begin{array}{l}\text { Fear conditioning } \\
\text { expression }\end{array}$ & $\begin{array}{l}\text { PTSD and generalized } \\
\text { anxiety }\end{array}$ & Rats & $\begin{array}{l}\text { Prevented fear expression } \\
(10 \mathrm{mg} / \mathrm{kg})\end{array}$ & $(22)$ \\
\hline $\begin{array}{l}\text { Fear conditioning } \\
\text { extinction }\end{array}$ & PTSD & Rats & $\begin{array}{l}\text { Bidirectional effect (facilitated extinction } \\
\text { when the conditioning stimulus was of } \\
\text { high-intensity) }\end{array}$ & $(23)$ \\
\hline $\begin{array}{l}\text { Reconsolidation of } \\
\text { aversive memories }\end{array}$ & PTSD & Rats & $\begin{array}{l}\text { Prevented reconsolidation } \\
(10 \mathrm{mg} / \mathrm{kg})\end{array}$ & $(24,25)$ \\
\hline Marble burying & OCD & Mice & Anti-compulsive (15-60 mg/kg) & $(26,27)$ \\
\hline \multicolumn{5}{|c|}{ REPEATED ADMINISTRATION } \\
\hline CUS & $\begin{array}{l}\text { Generalized anxiety and } \\
\text { depression }\end{array}$ & Mice & $\begin{array}{l}\text { Anti-stress (EPM and NSF; } 30 \text { mg/kg daily, } \\
14 \text { days) }\end{array}$ & $(28)$ \\
\hline Elevated T-maze & $\begin{array}{l}\text { Panic disorder and } \\
\text { generalized anxiety }\end{array}$ & Rats & Panicolytic (5 mg/kg/daily, 21 days) & $(29)$ \\
\hline $\begin{array}{l}\text { Delayed responses } \\
\text { to acute stress } \\
\text { (predator exposure) }\end{array}$ & PTSD & Rats & Anxiolytic (5 mg/kg daily, 7 days) & (30) \\
\hline Marble burying & OCD & Mice & Anti-compulsive (30 mg/kg daily, 7 days) & $(26)$ \\
\hline
\end{tabular}

EPM, elevated plus-maze; NSF, novel suppressed feeding; PTSD, post-traumatic stress disorder; OCD, obsessive-compulsive disorder; CUS, chronic unpredictable stress. 
responses, such as the medial prefrontal cortex (mPFC), dorsal periaqueductal gray (dPAG), bed nucleus of the stria terminallis (BNST), amygdala, and hippocampus. As shown in Figure 2, $\mathrm{CBD}$ induced acute anxiolytic effects when injected into the dPAG and BNST $(21,37-41)$. CBD also modified anxiety-like behaviors in the $\mathrm{mPFC}$, preventing the expression of contextual fear conditioning (41). However, when CBD was tested in the EPM, the picture proved more complicated, as the drug produced opposite effects when injected into the prelimbic or infralimbic regions of the mPFC. In these regions the effects reported varied according not only to the animal model employed but also to previous stress experience $(42,43)$. Inconsistent results were found following CBD injections into the amygdala after CBD administration (unpublished data). Regarding the hippocampus, although the acute effect of CBD on this structure is still unknown, repeated administration of the drug prevented the anxiogenic effect of chronic stress by facilitating hippocampal neurogenesis (44).

The acute anti-stress effects of CBD also involve the BNST (45) whereas its antidepressant action could be mediated by the hippocampus (44) and mPFC (34).

The pharmacological mechanisms involved in the anxiolytic/antidepressant properties of CBD have also recently been investigated. The acute effects of $\mathrm{CBD}$ clearly depend on facilitation of serotonin 5HT1A receptormediated neurotransmission in defense-related areas $(28,31,39,40,42,43,46,47)$. Gomes et al., (48) Not all CBD effects, however, are related to this mechanism (46). Since $\mathrm{CBD}$ can decrease the metabolism/uptake of anandamide, a major endocannabinoid, it could also act through this system. Indeed, the acute effects of $\mathrm{CBD}$ in the marble burying test and aversive memory reconsolidation were prevented by CB1-receptor antagonists $(24,26)$. Facilitation of CB1- and CB2mediated responses, probably due to inhibition of anandamide metabolism, is also involved in the pro-neurogenic effect of CBD (44). Finally, we have also shown that the inverted bell-shaped dose-response curve produced by CBD in several animal models of anxiety/depression is related to the activation of TRPV1

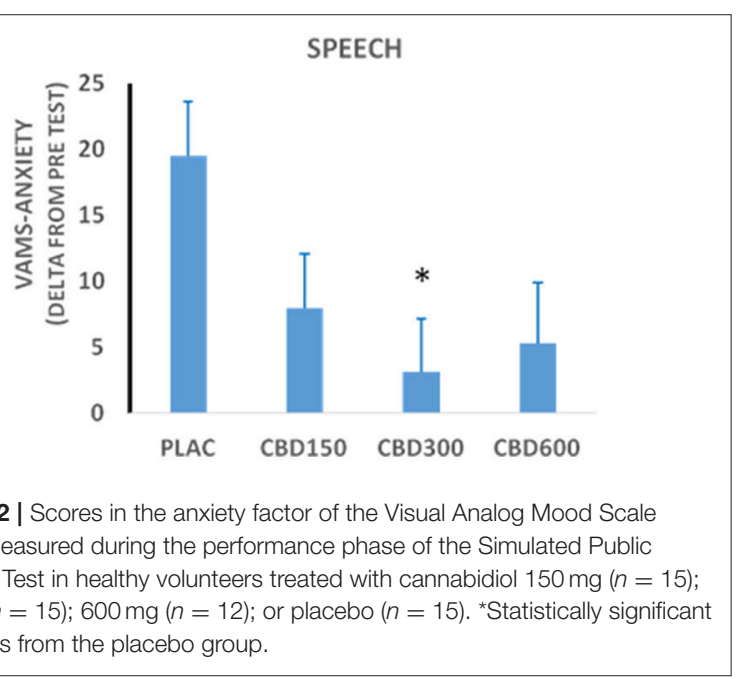

receptors that occurs at higher doses (49). These receptors could increase glutamate release, which would oppose 5HT1A- or CB1-mediated anxiolytic/antidepressant effects.

\section{Human Studies}

According to comprehensive reviews, acute and chronic administration of $\mathrm{CBD}$ by various routes (oral, inhaled, intravenous) to healthy volunteers and patients with different clinical conditions did not induce significant adverse effects $(50,51)$, especially because a conversion of oral cannabidiol to THC seems not to occur in humans (52). These results support previous observations from animal studies according to which $\mathrm{CBD}$ appears to be a safe compound for human use over a wide dose range.

The potential anxiolytic effect of CBD was first studied in healthy volunteers using the Simulated Public Speaking Test (SPST). In this model, subjects are asked to speak for a few minutes in front of a video camera while the subjective state of anxiety and its physiological concomitants (heart rate, blood pressure, skin conductance) are recorded. The SPST was shown to be effective in inducing anxiety and sensitive to many anxiogenic and anxiolytic compounds. Through this test, the effects of CBD $(300 \mathrm{mg}$ ) were compared with those produced by two anxiolytic compounds, ipsapirone $(5 \mathrm{mg})$ and diazepam $(10 \mathrm{mg})$, in a double-blind, placebo-controlled procedure. The findings demonstrated that $\mathrm{CBD}$ and the two other anxiolytic compounds all attenuated anxiety induced by the SPST (53).

The apparent validity of the SPST is intrinsic to social anxiety disorder (SAD), since the fear of public speaking and its physiological companions are considered fundamental aspects of this anxiety disorder. Nonetheless, no studies had dealt with the anxiolytic effects of CBD in pathological anxiety until then. We thus investigated this issue in 12 SAD patients treated with CBD $600 \mathrm{mg}, 12 \mathrm{SAD}$ patients who received placebo, and 12 healthy subjects who completed the SPST without receiving any medication (54). The group of SAD patients treated with CBD had lower anxiety levels in the performance and anticipatory phases of the test, lower negative self-assessment scores and fewer somatic symptoms compared with $\mathrm{SAD}$ patients who received placebo. Furthermore, no significant differences were found between SAD patients treated with CBD and healthy controls, unlike what happened with SAD patients taking placebo.

We evaluated the effects of different doses of CBD on the SPST in 57 healthy male volunteers divided into four groups (placebo, $n=15$; CBD $150 \mathrm{mg}, n=15$; CBD $300 \mathrm{mg}, n=15$; and CBD $600 \mathrm{mg}, n=12$ ) (55). The results confirmed the anxiolytic effect of CBD and the expected inverted "bell-shaped" doseresponse curve was observed (Figure 3), in agreement with the findings from animal studies described above. More recently, we further confirmed and expanded this finding with subjects who were assigned to five groups that received CBD $(100,300$, and $900 \mathrm{mg})$, the benzodiazepine clonazepam ( $1 \mathrm{mg}$ ) and placebo and underwent a test of public speaking in a real situation (TPSRS) where each volunteer had to speak in front of a group composed by the other participants. Again, the acute administration of CBD produced anxiolytic effects with a dose-dependent bell-shaped curve in healthy subjects, since the personal anxiety quantities 
were reduced with CBD $300 \mathrm{mg}$, but not with the other CBD doses of 100 and $900 \mathrm{mg}$ (56). Therefore, these results highlight the need to establish the accurate therapeutic dose ranges of $\mathrm{CBD}$ for each clinical condition.

\section{Brain Imaging of the Anxiolytic Effects of CBD}

The first neuroimaging study conducted to investigate the central effects of CBD in humans used single-photon emission computed tomography (SPECT) to evaluate healthy volunteers who received CBD $(400 \mathrm{mg})$ or placebo in two laboratory sessions, 1 week apart, in a crossover, double-blind procedure (57). The whole procedure induced anxiety (58), allowing the investigation of potential anxiolytic effects of CBD. The SPECT results showed an increase in the left parahippocampal gyrus activity and a decrease in left amigdala-hippocampus complex, extending to the left posterior cingulate cortex and the hypothalamus (Figure 4). This brain activity pattern associated with the use of CBD was regarded as compatible with a central anxiolytic effect in these areas.

In a series of neuroimaging studies, functional magnetic resonance imaging ( $\mathrm{fMRI}$ ) was used to investigate the neural correlates of the anxiolytic effects of CBD in 15 healthy subjects (60). This method allowed the acquisition of larger number of images with better spatial and temporalresolution. CBD (600 mg) modulated the patterns of brain activity while subjects processed stimuli depicting intensely fearful faces, attenuating responses in the anterior and posterior cingulate and amygdala. Moreover, this finding had a direct correlation with the concomitant effect of CBD in the modulation of skin conductance responses to fearful stimuli. In a subsequent study, it was also demonstrated that CBD

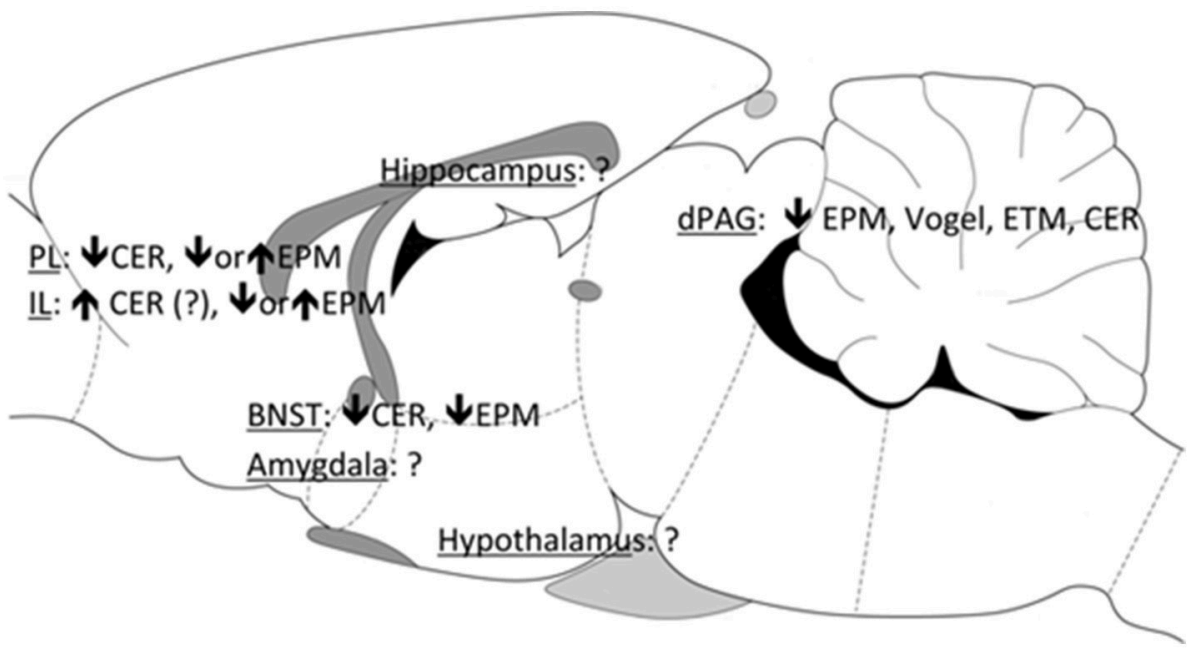

FIGURE 3 | Brain sites associated with the anxiolytic effects of CBD. PL, prelimbic mPFC; IL, infralimbic mPFC; BNST, bed nucleus of the stria terminallis; dPAG, dorsal periaqueductal gray; EPM, elevated plus maze; CER, conditioned emotional response; ETM, elevated T-maze.

A

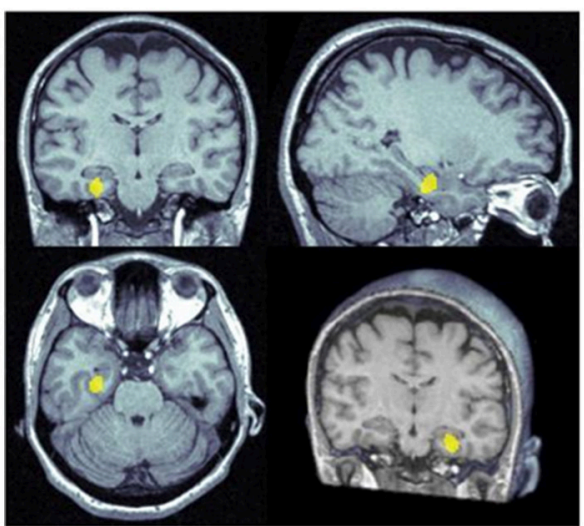

B

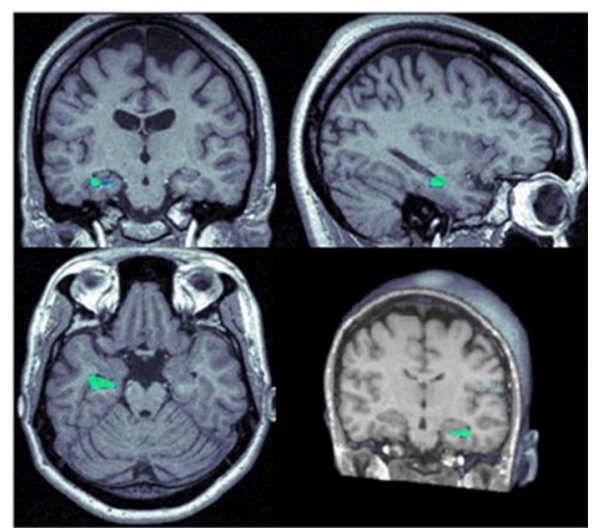

FIGURE 4 | Focus of significantly increased (yellow) and decreased (blue) rCBF in the left hippocampal area in healthy subjects (A) (57) and subjects with social anxiety disorder (SAD; B) (59) following the administration of CBD vs. placebo. 
produces its anxiolytic effects by altering prefrontal-subcortical connectivity via amygdala and the anterior cingulate (61).

More recently, we performed the first study to examine the neural correlates of the anxiolytic effects of CBD in a clinical sample (59), using the same protocol, design and dose (400 mg) as in the SPECT study with healthy volunteers described above (57). We found that, when compared to placebo, CBD was able to reduce subjective measures of anxiety without inducing sedation in treatment-naive SAD patients. The anxiolytic effect was associated with reduced activity in the hippocampus, parahippocampal and left temporal gyrus, and increased activity in the posterior cingulated (Figure 4).

Together, these results show that the modulatory effects of $\mathrm{CBD}$ in limbic and paralimbic areas are compatible with the effects of anxiolytic compounds on healthy subjects and in patients with anxiety disorders (62-64).

\section{Antipsychotic-Like Effects of CBD Studies With Animal Models}

Using classical animal models to evaluate antipsychotic effects, Zuardi et al. (65) made a pioneering investigation and showed that CBD decreased stereotypy induced by dopaminergic agonists, an effect similar to that of haloperidol. As opposed to the latter, however, CBD did not induce catalepsy, a motor impairment associated with antipsychotic extrapyramidal side effects in humans. Moreover, CBD only increased prolactin levels at high doses (greater than $120 \mathrm{mg} / \mathrm{kg}$, Table 2). These effects were similar to those of clozapine, suggesting that CBD could have an atypical antipsychotic profile (65).

Later, we showed that CBD is also able to decrease hyperlocomotion and pre-pulse inhibition (PPI) impairment induced by amphetamine in both mice and rats $(67,69)$ (Table 2$)$. The investigations were expanded to glutamatergic-based animal models of schizophrenia, which showed that CBD decreased hyperlocomotion and PPI impairment caused by the glutamate NMDA receptor non-competitive antagonists ketamine and MK801, respectively $(67,71)$. In the former study, CBD was administered chronically (for 21 days) and was also able to decrease the social impairment and memory deficits induced by the repeated administration of MK801 (70). Again, these effects were similar to those of the antipsychotic clozapine. In fact, mirroring earlier clinical findings (see below), CBD doses that produce antipsychotic-like effects are usually higher than those with anxiolytic action (see Tables 1, 2). Interestingly, in promising a recent study we found that peripubertal treatment with CBD inhibited the development of hyperlocomotion induced by prenatal treatment with poly I:C, indicating that this cannabinoid may have long-lasting properties of a peripubertal treatment as an intervention to prevent psychosis exhibited in the adulthood (72). The translations of these findings to ultrahigh-risk subjects to psychosis and in individuals in the early prodromal phases of schizophrenia of great importance, thus studies in this area are underway.

CBD did not induce catalepsy in any of the investigations available to date. In fact, CBD prevented and partially reversed catalepsy caused by haloperidol (48). As discussed below, this result is consonant with the clinical finding that $\mathrm{CBD}$, in addition to blocking L-DOPA-induced psychotic symptoms, may also improve motor impairment in Parkinson's patients (73).

\section{Mechanisms and Possible Brain Sites of CBD's Antipsychotic Effects}

In an early work, we observed that CBD produced a pattern of neuronal activation (measured by the expression of the protooncogene $c F o s$ ) similar to that of clozapine, but distinct from haloperidol. Whereas the three drugs increased activation in limbic areas, only CBD and clozapine increased activation in the mPFC. Haloperidol, on the other hand, induced a significant increase in cFos expression in the striatum (68). Confirming the involvement of limbic sites in its antipsychotic effects, CBD blocked PPI impairment induced by amphetamine after direct injection into the nucleus accumbens (71).

In respect to the implication of the $\mathrm{mPFC}$ in CBD's antipsychotic action, we showed that CBD, as well as the atypical antipsychotic clozapine, prevented the decrease in the expression of parvalbumin (a calcium-binding protein expressed in a subset of GABAergic interneurons) and the increase in Fos $B / \triangle$ Fos $B$ expression in the $\mathrm{mPFC}$ after chronic injection of the NMDA antagonist MK-801 (70). Although this latter result seems to contrast with the evidence on $\mathrm{cFos}$ mentioned above, $F o s B / \triangle F o s B$ is a marker of neuronal activation after repeated, not acute, stimulation. Finally, both $\mathrm{CBD}$ and clozapine prevented the increase in the number of GFAP-positive astrocytes in the $\mathrm{mPFC}$ and in the percentage of Iba-1-positive microglia cells with a reactive phenotype in the dorsal hippocampus and mPFCafter repeated administration of MK-801 (71). This result suggests that the anti-inflammatory action of CBD (see (30), for a review), could be related to its antipsychotic properties and is consonant with recent findings that anti-inflammatory drugs such as minocycline could be useful in the treatment of schizophrenia (74).

\section{Human Studies}

In 1995, Zuardi and colleagues published the first case report of a schizophrenia patient treated with CBD (66). A female patient with severe side effects from conventional antipsychotics was treated with CBD up to $1,500 \mathrm{mg} /$ day for 4 weeks and had a significant reduction in the positive and negative Brief Psychiatric Rating Scale (BPRS) symptom scores. In a later trial, three male patients with treatment-resistant schizophrenia were treated with CBD (up to $1,280 \mathrm{mg} /$ day) for 30 days, but only one had a partial improvement (75). The fact that, from the two schizophrenia patients who did not respond, one reduced psychotic symptoms only with clozapine and the other was resistant even to this drug, may justify the findings. None of the patients presented side effects while in treatment with $\mathrm{CBD}$, as previously observed in schizophrenic patients who received CBD and were assessed with electrodermal responsiveness to auditive stimuli and the Stroop Color Word Test (76).

Later, three double blind, controlled clinical trials that investigated the efficacy and tolerability of CBD in schizophrenia patients confirmed our preliminary findings. One study compared the effects of CBD (up to $800 \mathrm{mg} /$ day) to amisulpride in 42 schizophrenia patients treated for 4 weeks (77). Both 
TABLE 2 | Preclinical studies: antipsychotic-like effects of cannabidiol.

\begin{tabular}{|c|c|c|c|c|c|}
\hline Model & Species & $\begin{array}{l}\text { CBD effect } \\
\text { (dose range } \\
\text { in } \mathrm{mg} / \mathrm{kg} \text { ) }\end{array}$ & $\begin{array}{l}\text { Clozapine } \\
\text { effect }\end{array}$ & $\begin{array}{l}\text { Haloperidol } \\
\text { effect }\end{array}$ & References \\
\hline \multicolumn{6}{|l|}{ "DOPAMINERGIC" MODELS } \\
\hline $\begin{array}{l}\text { Stereotypies induced by DA } \\
\text { agonists }\end{array}$ & Rats & $\boldsymbol{v}_{(60)}$ & N.T. & $\sqrt{1}$ & (65) \\
\hline Catalepsy & $\begin{array}{l}\text { Rats, } \\
\text { mice }\end{array}$ & $=$ & $=$ & & (66) \\
\hline $\begin{array}{l}\text { Hyperlocomotion induced } \\
\text { by amphetamine }\end{array}$ & Mice & $(30-60)$ & & & (67) \\
\hline $\begin{array}{l}\text { PPI impairment by } \\
\text { amphetamine }\end{array}$ & Mice & $\boldsymbol{\nu}_{(15-60)}$ & & & (69) \\
\hline \multicolumn{6}{|c|}{ “GLUTAMATERGIC” MODELS } \\
\hline $\begin{array}{l}\text { Hyperlocomotion induced } \\
\text { by ketamine }\end{array}$ & Mice & $\begin{array}{l}\boldsymbol{W}(15-60, \\
\text { bell-shaped } \\
\text { dose- } \\
\text { response } \\
\text { curve) }\end{array}$ & $y$ & 4 & (67) \\
\hline $\begin{array}{l}\text { PPI impairment by MK801 } \\
(21 \text { days })^{\star}\end{array}$ & Mice & $\begin{array}{l}\text { (30-60 } \\
\text { daily, for } 21 \\
\text { days) }\end{array}$ & & N.T. & (70) \\
\hline
\end{tabular}

DA, dopamine; MPFC, medial prefrontal cortex; N.T., not tested; "repeated CBD also prevented memory (measured with the object recognition test) and social interaction impairment induced by repeated MK801. Reduction (or decrease), 1 Increase.

treatments significantly reduced psychotic symptoms, with no differences between them; however, CBD induced fewer side effects compared to amisulpride.

The antipsychotic effects of CBD were also investigated in first-episode schizophrenia patients treated for 14 days in a crossover, placebo-controlled trial (78). CBD significantly decreased psychotic symptoms after 2 weeks when compared to baseline, although the differences from placebo failed to reach statistical significance.

More recently, in a double-blind trial, patients with schizophrenia were randomized to receive for 6 weeks CBD $(1,000 \mathrm{mg} /$ day; $N=43)$ or placebo $(N=45)$ added-on to their existing antipsychotic medications (79). After the treatment, the CBD group presented lower positive psychotic scores and improved cognitive and general illness symptoms. CBD and placebo side-effects were equivalents between groups. Since the antipsychotic effects of CBD do not appear to depend on dopamine receptor antagonism, this compound may indeed represent a new class of treatment for the psychotic disorders in general and schizophrenia, in particular.

The view that CBD could have antipsychotic effects was further supported by our studies in healthy human subjects with artificially induced psychosis $(80,81)$. In a double blind, placebo-controlled trial, CBD (600 mg) was shown to attenuate depersonalization symptoms induced by the N-methylD-aspartate (NMDA) receptor antagonist ketamine, which increases glutamate release at low doses (80). This effect on dissociative symptoms also raised hypotheses of potential therapeutic uses of CBD in conditions such as post-traumatic stress disorder (PTSD), intoxication by cannabis, and some personality disorders.

The management of frequent psychotic symptoms in patients with Parkinson's disease (PD) is regarded as a major challenge for clinicians. It is particularly concerning because (i) the reduction of the doses of antiparkinsonian medications or the addition of conventional antipsychotics worsens motor function; and (ii) atypical antipsychotics may have significant side effects (especially in the neurological and hematological domains) (82). Thus, considering the pertinence of a possible antipsychotic effect of CBD and the lack of effective and safe pharmaceutical management for psychosis in $\mathrm{PD}$, we evaluated the efficacy and safety of this cannabinoid in patients with PD who had psychotic symptoms (73). In an open clinical trial with six PD outpatients, we found a significant reduction in the BPRS and the Parkinson Psychosis Questionnaire (PPQ) scores with CBD (150-600 mg/day) added to the usual treatment. Interestingly, 
we observed a reduction of both psychotic and motor symptoms during $\mathrm{CBD}$ treatment, with no worsening on cognition. These preliminary results suggested that $\mathrm{CBD}$ could have potential beneficial effects in $\mathrm{PD}$, which led us to investigate this possibility in greater depth (see below).

\section{Brain Imaging of the Antipsychotic Effects of CBD}

In a series of collaborative fMRI studies, the effects of CBD were investigated on behavior and regional brain activity in several areas, providing initial clues about its mechanisms and sites of action. Interestingly, opposite brain activation patterns following the administration of CBD $(600 \mathrm{mg})$ and $\triangle 9$-THC $(10 \mathrm{mg})$ were observed $(62,83)$. In contrast to placebo, the psychosis-like effects provoked by $\triangle 9$-THC were associated with decreased activation of (i) the dorsal striatum during "oddball" stimuli processing (84); (ii) the ventral striatum and anterior cingulate gyrus during word recall (85); and (iii) the right temporal cortex during auditory processing (86). In all these areas (traditionally associated with psychosis), the effects of CBD on brain activation were contrary to those of $\triangle 9$-THC, suggesting that they may be involved in the antipsychotic properties of CBD.

In a subsequent experiment, IV pre-treatment with $\mathrm{CBD}$ $(5 \mathrm{mg})$ prevented the psychotic symptoms induced by IV $\triangle 9$-THC (1.25 mg) (85). It was thus possible to hypothesize that the opposing effects of these two cannabinoids on brain modulation could be related both to their antagonism but also to the intrinsic antipsychotic effect of CBD. These findings are consistent with the observation that marijuana users of samples containing higher $\mathrm{CBD}$ concentrations in addition to $\triangle 9$-THC are less likely to experience psychotic symptoms than those who smoke samples without CBD (87).

\section{CONTEMPORARY DAYS: CBD AS A COMPOUND WITH A WIDE SPECTRUM OF ACTION (2000s-2010s)}

The cloning and description of the CB1 and CB2 cannabinoid receptors in the central system and the subsequent isolation of the endocannabinoids in the early 1990s renewed the interest in the investigation of cannabinoid compounds (2). As a result, there has been a constant increase in the number of investigations on CBD since then, stimulated mainly by discoveries of new therapeutical possibilities of the drug.

\section{Antiparkinsonian, Anti-oxidative, and Neuroprotective Actions}

Although the endocannabinoid system has aroused a promising target in the field of neuroprotection, no trials to date have assessed neuroprotective treatments with CBD for PD. Thus, following an open-trial evaluating the antipsychotic effects of CBD in PD with psychotic features, we tested this cannabinoid in $\mathrm{PD}$ patients with no psychiatric comorbidities or dementia (88). We selected $21 \mathrm{PD}$ patients that were assigned to three groups treated with placebo $(n=7), \mathrm{CBD} 75 \mathrm{mg} /$ day $(n=7)$, and CBD $300 \mathrm{mg} /$ day $(n=7)$. The participants were assessed at baseline and after treatment in regard to motor and general symptoms (UPDRS), quality of life and well-being (PDQ-39), and neuroprotective effects (BDNF levels and H1-MRS). The group treated with CBD $300 \mathrm{mg} /$ day presented significantly lower scores in the PDQ-39. Our findings suggest that CBD may be able to improve general parkinsonism in PD patients with no psychiatric comorbidities. In a series of collaborative animal studies, CBD was unable to prevent or reverse hyperlocomotion induced by the chronic injection of D-AMPH $(2 \mathrm{mg} / \mathrm{kg})$. However, we found that $\mathrm{CBD}$ seems to have antioxidant and neuroprotective properties, as it increased the levels of brain-derived neurotrophic factor $(89,90)$. In addition, CBD increased mitochondrial complex and creatine kinase activity (91), reversed oxidative stress parameters (TBARS formation and protein carbonyls) (92), and prevented cognitive impairments $(92,93)$. In another study, acute and chronic CBD administration $(10.0 \mathrm{mg} / \mathrm{kg})$ was able to rescue memory rats treated with iron (94). More recently, we found that CBD reversed iron-induced effects, normalizing hippocampal DNM1L, synaptophysin, and caspase 3 levels in rats and once again suggesting that CBD should be considered as a compound with neuroprotective and memory-rescuing properties (95).

\section{Neuroprotective and Neuroplasticity Increasing Drug}

Our brain continually changes in the course of our lifetime, and the investigation of mechanism involving neuroplasticity offers a great opportunity for the study of maladaptive mechanisms that lead to mental illness and possible new targets for their treatment (96). Neuropsychiatric disorders might be a result of profound changes in mechanism related to brain functions probably involving neuroplasticity (97). For instance, reduced hippocampal volume is observed in patients diagnosed with mood disorders, post-traumatic stress disorder (PTSD), schizophrenia and Alzheimer's Disease (98).

In rodents, exposure to protocol of chronic stressors, that modeling some features of psychiatric disorders symptoms, induce alterations in dendritic remodeling and decrease adult hippocampal neurogenesis $(38,44,99)$. Adult hippocampal neurogenesis is complex multi-step process that covers division, survival (not all neurons that divide will survive), migration and differentiation of new cells in the dentate gyrus of the hippocampus $(100,101)$. In the hippocampus, this process is thought to be determinant in at least some forms of learning and memory. Disturbed adult hippocampal neurogenesis has been recognized as one of the central mechanisms related to the reduction of hippocampal volume reported in patients suffering from mood disorders and schizophrenia. Lower rates of hippocampal neurogenesis were found in post-mortem tissues of schizophrenia patients and depressive patients $(102,103)$.

Derivatives of Cannabis sp have been investigated for their potential effects on neuroplasticity. In 2005, Jiang and co-workers observed that the chronic treatment with a synthetic cannabinoid (HU210) enhanced neurogenesis in rats. Regarding CBD, Wolf et al. (104) were the first to observe that after 6 weeks treatment with a CBD-rich diet, mice exhibited an increased number of neurons positive for the thymidine analog, 
bromodeoxyuridine (BrdU), in the hippocampus. Results from a different, suggested that besides of promoting adult hippocampal neurogenesis in mice kept basal conditions, CBD (administered intraperitoneally during 15 days) prevented the neurogenic disruption observed in a genetic murine model of Alzheimer's Disease through a peroxisome proliferator-activated receptor $\gamma$ (PPAR $\gamma)$-dependent mechanism (105). Results from our group suggested that in chronically stressed mice, CBD prevents stress-induced decreased hippocampal neurogenesis and stressinduced anxiogenesis. However, in transgenic GFAP/Thymidine kinase mice treated with ganciclovir, a model of disrupted adult neurogenesis, CBD was not able to prevent the effects of stress response. These results indicated that the behavioral effect of CBD in stressed mice was partially dependent on the integrity of the neurogenic capacity of the hippocampus.

Recently, Schiavon et al. (106) showed that CBD increased stress-coping behaviors in a behavioral test largely used for the screening of antidepressant drugs, suggested that CBD induces an increased the number of Ki67, BrdU, and double cortin-positive cells in the hippocampus. Interesting, Demirakca et al. (107) suggested that in chronic heavy user of Cannabis, higher THC and lower concentrations of CBD were associated with diminishing gray matter in the hippocampus and reduced cognitive performance, while higher levels of $\mathrm{CBD}$ in the consumed Cannabis samples prevented THC induced neurotoxic effects. In their discussion session, authors suggested that a possible mechanism involved in CBD neuroprotective would be its effects in facilitating hippocampal neurogenesis (107).

Studies also suggested that CBD has positive effects on synaptic remodeling. In rats submitted iron overload inducedbrain damage, CBD normalized the expression of synaptophysin, an important vesicular protein related to proper synaptic function (95). Moreover, similar to the neurotrophic factor, nerve growth factor, CBD neuritogenesis in PC12 cells, increasing the expression of synaptophysin and synapsin I (108). CBD can modulate intracellular pathways directly connected with synaptic remodeling, such as Erk1/2 and Akt, in distinct types of cancer cell lines $(109,110)$. Its precise effects in diverse brain regions, however, are still unclear. For example, repeated CBD administration (14 days) decreased phosphorylated forms of Erk1/2 levels in the PFC and improved contextual fear conditioned responses and (111). In chronically stressed mice, chronic CBD administration also promoted dendritic remodeling and increased the expression of Synapsin I/II, PSD95, and p-GSK3 $\beta$ in the hippocampus of rodents submitted to CUS (112).

$\mathrm{CBD}$ also has antioxidants activity, acting against the exacerbation of oxygen/nitrogen species (ROS/RNS) production and consequently DNA oxidation, polyunsaturated fatty acids peroxidation and nitration/carbonylation of proteins, leading to cell injury or death (112).

In rat cortical neurons, CBD prevented NMDA-mediated neurotoxicity and oxidative damage in through a cannabinoid receptor-independent mechanism (113). CBD decreases the neuronal damage induced by $\beta$-amyloid protein deposit (105); (114-116) and attenuates the depletion of tyrosine hydroxylase, GABA and dopamine levels by modulating the expression of the inducible isoform of $\mathrm{NO}$ synthase and reducing the production of
ROS-generating NADPH oxidases (114-120). Furthermore, CBD exerts antioxidant activities against toxicity induced different agents, such as amphetamine $(89,116,121)$, and attenuates high-glucose-induced mitochondrial ROS production and the expression of pro-inflammatory molecules (122).

In newborn mice, submitted to hypoxic-ischemic brain damage, $\mathrm{CBD}$ reduces neuronal damage by reducing the deleterious effects of glutamate, IL-6, TNF alpha, COX-2, and iNOS (123). Using the middle cerebral artery occlusion as method to evaluate ischemia-reperfusion injury, CBD suppressed the reduction of cerebral blood flow after reperfusion, inhibited myeloperoxidase (MPO) activity in neutrophils and reduced the number of MPO immunopositive cells (124). Recently, Mori et al. (125) demonstrated that in mice that underwent to bilateral common carotid artery occlusion, CBD stimulated neurogenesis and, restores dendritic arbor and BDNF levels in the hippocampus. In cultured hippocampal neurons submitted to oxygen-glucose-deprivation/reperfusion, this phytocannabinoid enhances mitochondrial function and reduces oxidative stress (126)

CBD improved cognition, motor activity and BDNF levels in mice administered with thioacetamide, a drug that induces hepatic encephalopathy $(127,128)$ ). In animal models of Parkinson's disease, $\mathrm{CBD}$ protects neurons by preventing the tyrosine hydroxylase activity reduction and the dopamine depletion in the substantia nigra $(119,129)$.

CBD seem to protect neurons from death by enhancing the recycle of old/damaged cell components via facilitations of autophagic action. Autophagy, particularlly macroautophagy, is a lysosomal degradation pathway crucial to recycle injured organelles and promote cell survival, protecting the cell malfunction or death under stress conditions (130). Hosseinzadeh et al. (131), demonstrated that in a model of pilocarpine-induced seizure, the anticonvulsant effects of CBD might involve the activation of hippocampal autophagic machinery (131). Recent findings from our group suggest that chronic CBD treatment increase autophagy in animals submitted to CUS, as observed by its effect in phosphorylated form of mTOR, Beclin-1 and LC3, signaling proteins involved in autophagy induction (112).

\section{Antiepileptic Action}

Still in the 1970s, the anticonvulsant effects of CBD were one of the first pharmacological properties of the drug described both in animals $(132,133)$ and in a preliminary clinical trial in patients led by the same Brazilian group (134). In a recent collaborative animal study, we found that $\mathrm{CBD}$ has protective effects not only on seizure control, but also against neuronal death in a model of mesial temporal lobe epilepsy induced by intrahippocampal pilocarpine (135).

We have recently investigated two cases of children with treatment-resistant epilepsy who had full seizure remission, but presented symptoms of intoxication by $\triangle 9$-THC and eventual seizure relapse with the use of a cannabidiol-enriched extract (136). When the extract was replaced by pure pharmaceuticalgrade $\mathrm{CBD}$, the intoxication signs disappeared and both patients became seizure-free. These observations highlight 
the importance of GMP/GLP to ensure the development of drugs consistently produced and controlled according to international regulatory standards. More recently, open-blind and double-blind, controlled clinical trials investigated the efficacy, security and tolerability of $\mathrm{CBD}$ in children and adolescents with treatment-resistant epilepsy (particularly Dravet and Lennox-Gastaut syndromes) confirmed and expanded these preliminary findings (137-140). Another larger randomized clinical trial in children with treatment-resistant epileptic syndromes using high-quality and reliable CBD is currently underway [NCT02783092, (141)].

\section{Sleep Disorders}

One of the most commonly observed effects of CBD at higher doses is sedation (2). REM sleep behavior disorder (RBD) is a parasomnia distinguished by fails in muscle atonia during REM sleep associated with active behavior while dreaming and nightmares. Currently, options for the pharmacological management of RBD are limited. With this in mind, we made an open-trial involving four PD patients with RBD, which is considered a common problem in this movement disorder (142). All patients had a efficient and substantial reduction in the frequency of RBD-related events.

A crossover trial of the acute effects of $300 \mathrm{mg}$ of CBD on the sleep architecture of healthy volunteers has shown that this compound did not interfere with the sleep cycle (55). It is particularly important, since different from anxiolytic and antidepressant drugs such as benzodiazepines and SSRIs, acute administration of an anxiolytic dose of CBD is a safe and appear to preserve the sleep architecture. Thus, CBD may be potentially useful therapeutic option for a wide range of disorders.

\section{Addiction}

There is no approved pharmacological therapy for the treatment of disorders related to the use of cannabis today (143). Based on findings from animal studies, we treated an inpatient with heavy cannabis dependence and episodes of cannabis withdrawal syndrome with $\mathrm{CBD}$, which yielded positive results (144). This finding has been highlighted in Nature Medicine (v. 20, n. 2, pg. 107) as a case of potential success. Likewise, the lack of effective medicines to treat crack cocaine dependence is a clear indication of the need for further research in this field. In a collaborative animal study, we found that CBD protects against cocaineinduced seizures, possibly through activation of the mTOR pathway, with the concomitant reduction in glutamate release (145).

\section{Mood Stabilization}

Given the anticonvulsive, anti-anxiety, antidepressant, and antipsychotic actions of CBD described above, we hypothesized that $\mathrm{CBD}$ could have a pharmacological profile comparable to that of mood stabilizers. In a collaborative animal study, we initially tested this idea in an animal model of mania induced by chronic injection of $\mathrm{D}$-amphetamine (D-AMPH) at the dose of $2 \mathrm{mg} / \mathrm{kg}$ (89). In this model, however, CBD was not able to prevent or reverse the hyperlocomotion induced by D-AMPH.
In parallel, we investigated the direct efficacy of $\mathrm{CBD}$ in two bipolar affective disorder (BAD) patients in acute manic episodes (146). The patients had no improvement with CBD, which is in line with the negative finding in the animal model of mania and suggests that the drug is not effective in the treatment of manic episodes in BAD. However, new clinical trials assessing CBD effects in depression and anxiety in BAD patients are still necessary.

\section{Other Actions}

Over the past 10 years, there has been an exponential increase in the number of publications dealing with the effects of CBD, fostered by the discovery of additional effects of this cannabinoid $(2,64,83)$. To take part in the frontline of research in these new areas, Brazilian groups articulated to create the National Institute of Science and Technology for Translational Medicine (INCTTM), funded by the Brazilian National Council for Scientific and Technological Development (CNPq) (147). As a result of this network, we contributed with further evidence on the actions of CBD as a neuroprotector (148), an anti-inflammatory $(149,150)$, and a drug able to increase sleep periods (151), among other properties (152-158).

\section{NEW AGE: FROM CLINICAL TRIALS WITH CBD AND ITS ANALOGS TO MOLECULE-TARGETED THERAPY}

In order to discuss available evidence on $\mathrm{CBD}$ and their usefulness and safety for therapeutic use in neuropsychiatric disorders, public hearings and literature reports in different forums and publications occurred worldwide.

Moreover, Professor Raphael Mechoulam, from the Hebrew University of Jerusalem, responsible for the isolation and synthesis of major cannabinoids (including $\triangle 9$-THC in 1964 and $\mathrm{CBD}$ in 1963) and for the discovery of the endocannabinoid system (CB1 receptor in 1989 and anandamide in 1992), recently contacted the group to develop synthetic fluorinated analogs of CBD $(159,160)$. These compounds have a strong potential for knowledge transfer to the productive sector, which could enable the commercialization of CBD-based products and offer the possibility of benefits for patients suffering from many of health conditions.

\section{THE BATTLE TO DEFINE THE FUTURE: CBD MEDICAL USES AND LAW REGULATIONS}

The panorama of the regulating laws involving human research and medical use of CBD in Brazil has advanced considering in the last 3 years. In January of 2015, the Brazilian regulatory agency ANVISA decided to reclassify CBD from the schedule I regulation (forbidden substances such as THC) to a controlled substance, same category of antidepressants, for instance. Currently, the products containing CBD available for prescription and sales in Brazil are the ones from GW pharmaceutical (Sativex ${ }^{\circledR}$ and Epidioloex ${ }^{\circledR}$ ). However, the 
access of these products for Brazilian patients remain difficult due the high costs of the treatment.

In some countries, however, the medical use of $\mathrm{CBD}$ is a reality. In the United States, Cannabidiol is listed as controlled in Schedule I in the Code of Federal Regulations, described as a "derivative" or "component" of marijuana (21 USC 802Mead et al., (161)- Epilepsy and Behavior). However, since 2012 the medical use of Cannabis, including CBD, is a reality. In some US states, the law includes the "recreational" use of Cannabis. In Canada, Cannabis (marijuana) and its products remains a Schedule II drug under the Controlled Drug and Substances Act. Its production and distribution for medical purposes are regulated. However, the medical use of $\mathrm{CBD}$ is permitted under medical prescription. In Europe, the last version of the Cannabis Legislation showed that the use of Cannabisbased drugs is highly regulated. In none of the European Union countries the smoking of Cannabis for medical proposes has been authorized. So far, Sativex ${ }^{\circledR}$ and Epidioloex ${ }^{\circledR}$ are the cannabisbased drugs containing $\mathrm{CBD}$ that can be prescribed for patients [European Monitoring Centre for Drugs and Drug Addiction (2017), Cannabis legislation in Europe: an overview, Publications Office of the European Union, Luxembourg].

\section{CONCLUSION}

In conclusion, the experimental and clinical use of CBD, a compound that does not produce the typical subjective effects of marijuana induced by $\triangle 9$-THC, has clearly shown anxiolytic, antiepileptic, and antipsychotic properties, among other effects (2). Since the 1970 s, a number of scientific articles showing the potential therapeutic effects of $\mathrm{CBD}$ in different animal models of neuropsychiatric disorders and some clinical trials have been published. Recent investigations on the new effects of CBD and its synthetic analogs and on the comprehension of the mechanisms of action of this compounds as well as a better understanding of the endocannabinoid system have emerged. However, new questions appeared regarding the properties of $\mathrm{CBD}$ and its synthetic analogs that are currently under investigation, such as the safety and precise dose ranges for each disorder. Therefore, more controlled clinical trials with different and larger neuropsychiatric populations should bring important

\section{REFERENCES}

1. Carlini EA. Research with marijuana in Brazil. Rev Bras Psiquiatr. (2010) 32(Suppl 1):S3-4. doi: 10.1590/S1516-44462010000500002

2. Zuardi AW. Cannabidiol: from an inactive cannabinoid to a drug with wide spectrum of action. Rev Bras Psiquiatr. (2008) 30:271-80. doi: 10.1590/S1516-44462008000300015

3. Mechoulam R, Zuardi AW, Kapczinski FP, Hallak JEC, Guimaraes FS, Crippa JAS, et al. Fluorinated CBD Compounds, Compositions and Uses Thereof. Pub. No.: WO/2014/ 108899. International Application No.: PCT/IL2014/050023. (2014)

4. Adams R, Hunt M, Clark JH. Structure of cannabidiol, a product isolated from the marihuana extract of Minnesota wild hemp. J Am Chem Soc. (1940) 62:196-200. doi: 10.1021/ja01858a058 answers in the near future and support the translation of research findings to clinical settings.

\section{AUTHOR CONTRIBUTIONS}

All authors have been studying the effects of CBD at least for more than 20 years. AZ and JC wrote about the clinical and human data, whereas FG and AC wrote about the animal and preclinical data. JC combined both portions, edited, and added some discussion. FG produced the Figures and Tables.

\section{FUNDING}

AZ, FG, and JC are recipients of Conselho Nacional de Desenvolvimento Científico e Tecnológico (CNPq, Brazil) productivity fellowships (1A). Research was supported in part by grants from (i) Fundação de Amparo à Pesquisa do Estado de São Paulo (FAPESP); (ii) Conselho Nacional de Desenvolvimento Científico e Tecnológico (CNPq); (iii) Coordenação de Aperfeiçoamento de Pessoal de Nível Superior (CAPES); (iv) Fundação de Apoio ao Ensino, Pesquisa e Assistência do Hospital das Clínicas da Faculdade de Medicina de Ribeirão Preto da Universidade de São Paulo (FAEPA, Brazil); (v) Center for Interdisciplinary Research on Applied Neurosciences (NAPNA), University of São Paulo, São Paulo, Brazil (NAPNA); and (vi) National Institute for Translational Medicine (INCTTM; CNPq, Brazil). The present study was supported by a CNPq grant (CNPq/MS/SCTIE/DECIT N ${ }^{\circ}$ 26/2014-Pesquisas sobre Distúrbios Neuropsiquiátricos; 466805/2014-4). JC has a grant from University Global Partnership Network (UGPN) Global priorities in cannabinoid research excellence. STI-Pharm (Brentwood, UK), THC-Phram (Frankfurt, Germany), and BSPG-Pharm (Sandwich, UK) have kindly supplied CBD at no cost.

\section{ACKNOWLEDGMENTS}

Although unable to list every name that deserved mention here, we would like to thank our colleagues and collaborators from different centers in Brazil and other countries for their invaluable support in the investigation of CBD.
5. Izzo AA, Borrelli F, Capasso R, Di Marzo V, Mechoulam R. Nonpsychotropic plant cannabinoids: new therapeutic opportunities from an ancient herb. Trends Pharmacol Sci. (2009) 30:515-27. doi: 10.1016/j.tips.2009.07.006

6. Mechoulam R, Shvo Y. Hashish-I: structure of cannabidiol. Tetrahedron (1963) 19:2073-78. doi: 10.1016/0040-4020(63)85022-X

7. Mechoulam R, Shani A, Edery H, Grunfeld Y. Chemical basis of hashish activity. Science (1970) 169:611-12 doi: 10.1126/science.169.3945.611

8. Carlini EA, Santos M, Claussen U, Bieniek D, Korte F. Structure activity relationship of four tetrahydrocannabinols and the pharmacological activity of five semi-purified extracts of Cannabis sativa. Psychopharmacologia (1970) 18:82-93. doi: 10.1007/BF00402387

9. Karniol IG, Carlini EA. The content of (-) 9 -trans-tetrahydrocannabinol (9-thc) does not explain all biological activity of some Brazilian 
marihuana samples. J Pharm Pharmacol. (1972) 24:833-4. doi: 10.1111/j.2042-7158.1972.tb08897.x

10. Takahashi RN, Zuardi AW, Karniol IG. Composição química e importância dos diversos constituintes na atividade farmacológica de amostras de Cannabis sativa Brasileiras. Rev Bras Pesqui Med Biol. (1970) 10:379-85.

11. Karniol IG, Carlini EA. Pharmacological interaction between cannabidiol and (-) 9 -trans-tetrahydrocannabinol. Psychopharmacologia (1973) 30:5370. doi: 10.1007/BF00428793

12. Zuardi AW, Karniol IG. Effects on variable-interval performance in rats of delta 9-tetrahydrocannabinol and cannabidiol, separately and in combination. Braz J Med Biol Res. (1983) 16:141-146.

13. Zuardi AW, Teixeira NA, Karniol IC. Pharmacological interaction of the effects of delta 9-trans-tetrahydrocannabinol and cannabidiol on serum corticosterone levels in rats. Arch Int Pharmacodyn Ther. (1984) 269:12-9.

14. Zuardi AW, Hallak JEC, Crippa JA. Interaction between cannabidiol (CBD) and Delta 9-tetrahydrocannabinol (THC): influence of administration interval and dose ratio between the cannabinoids. Psychopharmacology (2012) 219:247-9. doi: 10.1007/s00213-011-2495-x

15. Zuardi AW, Shirakawa I, Finkelfarb E, Karniol IG. Action of cannabidiol on the anxiety and other effects produced by delta 9-THC in normal subjects. Psychopharmacology (1982) 76:245-50. doi: 10.1007/BF00432554

16. Zuardi AW, Finkelfarb E, Bueno OF, Musty RE, Karniol IG. Characteristics of the stimulus produced by the mixture of cannabidiol with delta 9tetrahydrocannabinol. Arch Int Pharmacodyn Ther. (1981) 249:137-46.

17. Zuardi AW, Karniol IG. Changes in the conditioned emotional response of rats induced by 9-THC, CBD and mixture of the two cannabinoids. Arq Biol TecnoI. (1983) 26:391-7.

18. Silveira Filho NG, Tufik S. Comparative effects between cannabidiol and diazepam on neophobia, food intake and conflict behavior. Res Commun Psychol Psychiatry Behav. (1981) 6:25-6.

19. Guimarães FS, Chiaretti TM, Graeff FG, Zuardi AW. Antianxiety effect of cannabidiol in the elevated plus-maze. Psychopharmacology (1990) 100:5589. doi: 10.1007/BF02244012

20. Guimarães FS, de Aguiar JC, Mechoulam R, Breuer A. Anxiolytic effect of cannabidiol derivatives in the elevated plus-maze. Gen Pharmacol. (1994) 25:161-4. doi: 10.1016/0306-3623(94)90027-2

21. Moreira FA, Aguiar DC, Guimarães FS. Anxiolytic-like effect of cannabidiol in the rat Vogel conflict test. Prog Neuropsychopharmacol Biol Psychiatry (2006) 30:1466-71. doi: 10.1016/j.pnpbp.2006.06.004

22. Resstel LB, Joca SR, Moreira FA, Corrêa FM, Guimarães FS. Effects of cannabidiol and diazepam on behavioral and cardiovascular responses induced by contextual conditioned fear in rats. Behav Brain Res. (2006) 172:294-8. doi: 10.1016/j.bbr.2006.05.016

23. Song C, Stevenson CW, Guimaraes FS, Lee JL. Bidirectional effects of cannabidiol on contextual fear memory extinction. Front Pharmacol. (2016) 7:493. doi: 10.3389/fphar.2016.00493

24. Stern CA, Gazarini L, Takahashi RN, Guimarães FS, Bertoglio LJ. On disruption of fear memory by reconsolidation blockade: evidence from cannabidiol treatment. Neuropsychopharmacology (2012) 37:2132-42. doi: $10.1038 / \mathrm{npp} .2012 .63$

25. Stern CA, Gazarini L, Vanvossen AC, Zuardi AW, GalveRoperh I, Guimaraes FS, et al. 89 -Tetrahydrocannabinol alone and combined with cannabidiol mitigate fear memory through reconsolidation disruption. Eur Neuropsychopharmacol. (2015) 25:958-65. doi: 10.1016/j.euroneuro.2015.02.001

26. Casarotto PC, Gomes FV, Resstel LB, Guimarães FS. Cannabidiol inhibitory effect on marble-burying behavior: involvement of CB1 receptors. Behav Pharmacol (2010) 21:353-8. doi: 10.1097/FBP.0b013e32833b33c5

27. Nardo M, Casarotto PC, Gomes FV, Guimarães FS. Cannabidiol reverses the mCPP-induced increase in marble-burying behavior. Fundam Clin Pharmacol. (2014) 28:544-50. doi: 10.1111/fcp.12051

28. Campos AC, Ferreira FR, Guimarães FS. Cannabidiol blocks longlasting behavioral consequences of predator threat stress: possible involvement of 5HT1A receptors. J Psychiatr Res. (2012) 46:1501-10. doi: 10.1016/j.jpsychires.2012.08.012

29. Campos AC, Ferreira FR, Guimarães FS, Lemos JI. Facilitation of endocannabinoid effects in the ventral hippocampus modulates anxiety-like behaviors depending on previous stress experience.
Neuroscience (2010) 167:238-46. doi: 10.1016/j.neuroscience.2010. 01.062

30. Campos AC, Moreira FA, Gomes FV, Del Bel EA, Guimarães FS. Multiple mechanisms involved in the large-spectrum therapeutic potential of cannabidiol in psychiatric disorders. Philos Trans R Soc Lond B Biol Sci. (2012) 367:3364-78. doi: 10.1098/rstb.2011.0389

31. Resstel LB, Tavares RF, Lisboa SF, Joca SR, Corrêa FM, Guimarães FS. 5HT1A receptors are involved in the cannabidiol-induced attenuation of behavioral and cardiovascular responses to acute restraint stress in rats. $\mathrm{Br}$ J Pharmacol. (2009) 156:181-8. doi: 10.1111/j.1476-5381.2008.00046.x

32. Granjeiro EM, Gomes FV, Guimarães FS, Corrêa FM, Resstel LB. Effects of intracisternal administration of cannabidiol on the cardiovascular and behavioral responses to acute restraint stress. Pharmacol Biochem Behav. (2011) 99:743-8. doi: 10.1016/j.pbb.2011.06.027

33. Zanelati TV, Biojone C, Moreira FA, Guimarães FS, Joca SR. Antidepressant-like effects of cannabidiol in mice: possible involvement of 5-HT1A receptors. Br J Pharmacol. (2010) 159:122-8. doi: 10.1111/j.1476-5381.2009.00521.x

34. Sartim AG, Guimarães FS, Joca SR. Antidepressant-like effect of cannabidiol injection into the ventral medial prefrontal cortex-Possible involvement of 5-HT1A and CB1 receptors. Behav Brain Res. (2016) 303:218-27. doi: 10.1016/j.bbr.2016.01.033

35. Shoval G, Shbiro L, Hershkovitz L, Hazut N, Zalsman G, Mechoulam $\mathrm{R}$, et al. Prohedonic effect of cannabidiol in a rat model of depression. Neuropsychobiology (2016) 73:123-9. doi: 10.1159/000443890

36. Linge R, Jiménez-Sánchez L, Campa L, Pilar-Cuéllar F, Vidal R, Pazos A, et al. Cannabidiol induces rapid-acting antidepressant-like effects and enhances cortical 5-HT/glutamate neurotransmission: role of 5-HT1A receptors. Neuropharmacology (2016) 103:16-26. doi: 10.1016/j.neuropharm.2015.12.017

37. Campos AC, Guimarães FS. Involvement of 5HT1A receptors in the anxiolytic-like effects of cannabidiol injected into the dorsolateral periaqueductal gray of rats. Psychopharmacology (2008) 199:223-30. doi: 10.1007/s00213-008-1168-x

38. Campos AC, de Paula Soares V, Carvalho MC, Ferreira FR, Vicente MA, Brandão $\mathrm{ML}$, et al. Involvement of serotonin-mediated neurotransmission in the dorsal periaqueductal gray matter on cannabidiol chronic effects in panic-like responses in rats. Psychopharmacology (2013) 226:13-24. doi: 10.1007/s00213-012-2878-7

39. Gomes FV, Reis DG, Alves FH, Corrêa FM, Guimarães FS, Resstel LB. Cannabidiol injected into the bed nucleus of the stria terminallis reduces the expression of contextual fear conditioning via 5-HT1A receptors. J Psychopharmacol. (2012) 26:104-13. doi: 10.1177/02698811103 89095

40. Soares Vde P, Campos AC, Bortoli VC, Zangrossi HJr, Guimarães FS, Zuardi AW. Intra-dorsal periaqueductal gray administration of cannabidiol blocks panic-like response by activating 5-HT1A receptors. Behav Brain Res. (2010) 213:225-9. doi: 10.1016/j.bbr.2010.05.004

41. Lemos JI, Resstel LB, Guimarães FS. Involvement of the prelimbic prefrontal cortex on cannabidiol-induced attenuation of contextual conditioned fear in rats. Behav Brain Res. (2010) 207:105-11. doi: 10.1016/j.bbr.2009.09.045

42. Fogaça MV, Reis FM, Campos AC, Guimarães FS. Effects of intraprelimbic prefrontal cortex injection of cannabidiol on anxietylike behavior: involvement of 5HT1A receptors and previous stressful experience. Eur Neuropsychopharmacol. (2014) 24:410-9. doi: 10.1016/j.euroneuro.2013.10.012

43. Marinho AL, Vila-Verde C, Fogaça MV, Guimarães FS. Effects of intra-infralimbic prefrontal cortex injections of cannabidiol in the modulation of emotional behaviors in rats: contribution of $5 \mathrm{HT} 1 \mathrm{~A}$ receptors and stressful experiences. Behav Brain Res. (2015) 286:49-56. doi: 10.1016/j.bbr.2015.02.023

44. Campos AC, Ortega Z, Palazuelos J, Fogaça MV, Aguiar DC, DíazAlonso J, et al. The anxiolytic effect of cannabidiol on chronically stressed mice depends on hippocampal neurogenesis: involvement of the endocannabinoid system. Int J Neuropsychopharmacol. (2013) 16:1407-19. doi: $10.1017 /$ S1461145712001502

45. Gomes FV, Alves FH, Guimarães FS, Correa FM, Resstel LB, Crestani CC. Cannabidiol administration into the bed nucleus of the stria 
terminallis alters cardiovascular responses induced by acute restraint stress through 5-HT1A receptor. Eur Neuropsychopharmacol. (2013) 23:1096-104. doi: 10.1016/j.euroneuro.2012.09.007

46. Schier, A. R., Ribeiro, N. P., Silva, A. C., Hallak, J. E., Crippa, J. A., and Nardi, A.,E., et al. (2012). Cannabidiol, a Cannabis sativa constituent, as an anxiolytic drug. Rev Bras Psiquiatr. 34(Suppl. 1) S104-10. doi: 10.1016/S1516-4446(12)70057-0

47. Gomes FV, Resstel LB, Guimarães FS. The anxiolytic-like effects of cannabidiol injected into the bed nucleus of the stria terminallis are mediated by 5-HT1A receptors. Psychopharmacology (2011) 213:465-73. doi: 10.1007/s00213-010-2036-Z

48. Gomes FV, Del Bel EA, Guimarães FS. Cannabidiol attenuates catalepsy induced by distinct pharmacological mechanisms via 5-HT1A receptor activation in mice. Prog Neuropsychopharmacol Biol Psychiatry (2013) 46:437. doi: 10.1016/j.pnpbp.2013.06.005

49. Campos AC, Guimarães FS. Evidence for a potential role for TRPV1 receptors in the dorsolateral periaqueductal gray in the attenuation of the anxiolytic effects of cannabinoids. Prog Neuropsychopharmacol Biol Psychiatry (2009) 33:1517-21. doi: 10.1016/j.pnpbp.2009.08.017

50. Bergamaschi MM, Queiroz RH, Zuardi AW, Crippa JA. Safety and side effects of cannabidiol, a Cannabis sativa constituent. Curr Drug Saf. (2011) 6:237-49. doi: $10.2174 / 157488611798280924$

51. Iffland $\mathrm{K}$, Grotenhermen $\mathrm{F}$. An update on safety and side effects of cannabidiol: a review of clinical data and relevant animal studies. Cannabis Cannabinoid Res. (2017) 2:139-54. doi: 10.1089/can.2016.0034

52. Nahler G, Grotenhermen F, Zuardi AW, Crippa JAS. A Conversion of oral cannabidiol to delta9-tetrahydrocannabinol seems not to occur in humans. Cannabis Cannabinoid Res. (2017) 2:81-6. doi: 10.1089/can.2017.0009

53. Zuardi AW, Cosme RA, Graeff FG, Guimarães FS. Effects of ipsapirone and cannabidiol on human experimental anxiety. J Psychopharmacol. (1993) 7:82-8. doi: 10.1177/026988119300700112

54. Bergamaschi MM, Queiroz RH, Chagas MH, de Oliveira DC, De Martinis BS, Kapczinski F, et al. Cannabidiol reduces the anxiety induced by simulated public speaking in treatment-naïve social phobia patients. Neuropsychopharmacology (2011) 36:1219-26. doi: 10.1038/npp.2011.6

55. Linares I, Zuardi AW, Pereira LC, Hallak JEC, Queiroz RHC, Guimarães FS, et al. Cannabidiol presents an inverted U-shaped dose-response curve in a simulated public speaking test. Eur. Neuropsychopharmacol. (2018) 26:S617. doi: 10.1016/S0924-977X(16)31702-3

56. Zuardi AW, Rodrigues NP, Silva AL, Bernardo SA, Hallak JEC, Guimarães FS, et al. Inverted U-shaped dose-response curve of the anxiolytic effect of cannabidiol during public speaking in real life. Front Pharmacol. (2017) 8:259. doi: 10.3389/fphar.2017.00259

57. Crippa JA, Zuardi AW, Garrido GE, Wichert-Ana L, Guarnieri R, Ferrari L, et al. Effects of cannabidiol (CBD) on regional cerebral blood flow. Neuropsychopharmacology (2004) 29:417-26. doi: 10.1038/sj.npp.1300340

58. Grey SJ, Price G, Mathews A. Reduction of anxiety during MR imaging: a controlled trial. Magn Reson Imaging (2000) 18:351-5. doi: 10.1016/S0730-725X(00)00112-0

59. Crippa JA, Derenusson GN, Ferrari TB, Wichert-Ana L, Duran FL, MartinSantos R, et al. Neural basis of anxiolytic effects of cannabidiol (CBD) in generalized social anxiety disorder: a preliminary report. J Psychopharmacol. (2011) 25:121-30. doi: 10.1177/0269881110379283

60. Fusar-Poli P, Crippa JA, Bhattacharyya S, Borgwardt SJ, Allen P, Martin-Santos R, et al. Distinct effects of \{delta\}9-tetrahydrocannabinol and cannabidiol on neural activation during emotional processing. Arch Gen Psychiatry (2009) 66:95-105. doi: 10.1001/archgenpsychiatry. 2008.519

61. Fusar-Poli P, Allen P, Bhattacharyya S, Crippa JA, Mechelli A, Borgwardt S, et al. Modulation of effective connectivity during emotional processing by Delta9-tetrahydrocannabinol and cannabidiol. Int J Neuropsychopharmacol. (2009) 13:421-32. doi: 10.1017/S1461145709990617

62. Batalla A, Crippa JA, Busatto GF, Guimaraes FS, Zuardi AW, Valverde O, et al. Neuroimaging studies of acute effects of THC and CBD in humans and animals: a systematic review. Curr Pharm Des. (2014) 20:2168-85. doi: 10.2174/13816128113199990432

63. Batalla A, Bhattacharyya S, Yücel M, Fusar-Poli P, Crippa JA, Nogué S, et al. (2013). Structural and functional imaging studies in chronic cannabis users: a systematic review of adolescent and adult findings. PLoS ONE 8:e55821. doi: 10.1371/journal.pone.0055821

64. de Mello Schier AR, de Oliveira Ribeiro NP, Coutinho DS, Machado S, AriasCarrión O, Crippa JA, et al. Antidepressant-like and anxiolytic-like effects of cannabidiol: a chemical compound of Cannabis sativa. CNS Neurol Disord Drug Targets (2014) 13:953-60. doi: 10.2174/1871527313666140612114838

65. Zuardi AW, Rodrigues JA, Cunha JM. Effects of cannabidiol in animal models predictive of antipsychotic activity. Psychopharmacology (1991) 104:260-4. doi: 10.1007/BF02244189

66. Zuardi AW, Morais SL, Guimarães FS, Mechoulam R. Antipsychotic effect of cannabidiol. JClin Psychiatry (1995) 56:485-6.

67. Moreira FA, Guimarães FS. Cannabidiol inhibits the hyperlocomotion induced by psychotomimetic drugs in mice. Eur J Pharmacol. (2005) 512:199-205 doi: 10.1016/j.ejphar.2005.02.040

68. Guimarães VM, Zuardi AW, Del Bel EA, Guimarães FS. Cannabidiol increases Fos expression in the nucleus accumbens but not in the dorsal striatum. Life Sci. (2004) 75:633-8. doi: 10.1016/j.lfs.2004.01.015

69. Pedrazzi JF, Issy AC, Gomes FV, Guimarães FS, Del-Bel EA. Cannabidiol effects in the prepulse inhibition disruption induced by amphetamine. Psychopharmacology (2015) 232:3057-65. doi: 10.1007/s00213-015-3945-7

70. Gomes FV, Issy AC, Ferreira FR, Viveros MP, Del Bel EA, Guimarães FS. Cannabidiol attenuates sensorimotor gating disruption and molecular changes induced by chronic antagonism of NMDA receptors in mice. Int $J$ Neuropsychopharmacol. (2014) 18:pyu041. doi: 10.1093/ijnp/pyu041

71. Gomes FV, Llorente R, Del Bel EA, Viveros MP, López-Gallardo M, Guimarães FS. Decreased glial reactivity could be involved in the antipsychotic-like effect of cannabidiol. Schizophr Res. (2015) 164:155-63. doi: 10.1016/j.schres.2015.01.015

72. Peres FF, Diana MC, Suiama MA, Justi V, Almeida V, Bressan RA, et al. Peripubertal treatment with cannabidiol prevents the emergence of psychosis in an animal model of schizophrenia. Schizophr Res. (2016) 172:220-1. doi: 10.1016/j.schres.2016.02.004

73. Zuardi AW, Crippa JA, Hallak JE, Pinto JP, Chagas MH, Rodrigues GG, et al. Cannabidiol for the treatment of psychosis in Parkinson's disease. $J$ Psychopharmacol. (2009) 23:979-83. doi: 10.1177/0269881108096519

74. Chaves C, Marque C R, Maia-de-Oliveira JP, Wichert-Ana L, Ferrari $\mathrm{TB}$, Santos AC, et al. Effects of minocycline add-on treatment on brain morphometry and cerebral perfusion in recent-onset schizophrenia. Schizophr Res. (2015) 161:439-45. doi: 10.1016/j.schres.2014.11.031

75. Zuardi AW, Hallak JE, Dursun SM, Morais SL, Sanches RF, Musty RE, et al. Cannabidiol monotherapy for treatment-resistant schizophrenia. $J$ Psychopharmacol. (2006) 20:683-6. doi: 10.1177/0269881106060967

76. Hallak JE, Machado-de-Sousa JP, Crippa JA, Sanches RF, Trzesniak C, Chaves C, et al. Performance of schizophrenic patients in the Stroop Color Word Test and electrodermal responsiveness after acute administration of cannabidiol (CBD). Rev Bras Psiquiatr. (2010) 32:56-61. doi: 10.1590/S1516-44462010000100011

77. Leweke FM, Piomelli D, Pahlisch F, Muhl D, Gerth CW, Hoyer C. Cannabidiol enhances anandamide signaling and alleviates psychotic symptoms of schizophrenia. Transl Psychiatry (2012) 2:e94. doi: $10.1038 /$ tp. 2012.15

78. Leweke FM, Kranaster L, Pahlisch F, Klosterkötter F, Hellmich M, Piomelli D. The efficacy of cannabidiol in the treatment of schizophrenia - a translational approach. Schizophr Bull. (2011) 37(Supp 1):313.

79. McGuire P, Robson P, Cubala WJ, Vasile D, Morrison PD, Barron R, et al. Cannabidiol (CBD) as an adjunctive therapy in schizophrenia: a multicenter randomized controlled trial. Am J Psychiatry (2018) 175:225-31. doi: 10.1176/appi.ajp.2017.17030325

80. Hallak JE, Dursun SM, Bosi DC, de Macedo LR, Machado-de-Sousa JP, Abrão $\mathrm{J}$, et al. The interplay of cannabinoid and NMDA glutamate receptor systems in humans: preliminary evidence of interactive effects of cannabidiol and ketamine in healthy human subjects. Prog Neuropsychopharmacol Biol Psychiatry (2011) 35:198-202. doi: 10.1016/j.pnpbp.2010. 11.002

81. Martin-Santos R, Crippa JA, Batalla A, Bhattacharyya S, Atakan Z, Borgwardt $\mathrm{S}$, et al. Acute effects of a single, oral dose of d9-tetrahydrocannabinol (THC) and cannabidiol (CBD)administration in healthy volunteers. Curr Pharm Des. (2012) 18:4966-79. doi: 10.2174/138161212802884780 
82. Thanvi BR, Lo TC, Harsh DP. Psychosis in Parkinson's disease. Postgrad Med J. (2005) 81:644-6. doi: 10.1136/pgmj.2004.032029

83. Zuardi AW, Crippa JA, Hallak JE, Bhattacharyya S, Atakan Z, Martin-Santos $\mathrm{R}$, et al. A critical review of the antipsychotic effects of cannabidiol: 30 years of a translational investigation. Curr Pharm Des. (2012) 18:5131-40. doi: 10.2174/138161212802884681

84. Bhattacharyya S, Crippa JA, Allen P, Martin-Santos R, Borgwardt S, Fusar-Poli $\mathrm{P}$, et al. Induction of psychosis by $\Delta 9$-tetrahydrocannabinol reflects modulation of prefrontal and striatal function during attentional salience processing. Arch Gen Psychiatry (2012) 69:27-36. doi: 10.1001/archgenpsychiatry.2011.161

85. Bhattacharyya S, Morrison PD, Fusar-Poli P, Martin-Santos R, Borgwardt S, Winton-Brown T, et al. Opposite effects of delta-9-tetrahydrocannabinol and cannabidiol on human brain function and psychopathology. Neuropsychopharmacology (2010) 35:764-74. doi: 10.1038/npp.2009.184

86. Winton-Brown TT, Allen P, Bhattacharyya S, Borgwardt SJ, FusarPoli P, Crippa JA, et al.. Modulation of auditory and visual processing by delta-9-tetrahydrocannabinol and cannabidiol: an FMRI study. Neuropsychopharmacology (2011) 36:1340-8. doi: 10.1038/npp.2011.17

87. Morgan CJ, Gardener C, Schafer G, Swan S, Demarchi C, Freeman TP, et al. Sub-chronic impact of cannabinoids in street cannabis on cognition, psychotic-like symptoms and psychological well-being. Psychol Med. (2012) 42:391-400. doi: 10.1017/S0033291711001322

88. Chagas MH, Eckeli AL, Zuardi AW, Pena-Pereira MA, Sobreira-Neto MA, Sobreira ET, et al. Cannabidiol can improve complex sleep-related behaviors associated with rapid eye movement sleep behavior disorder in Parkinson's disease patients: a case series. J Clin Pharm Ther. (2014) 39:5646. doi: $10.1111 /$ jcpt.12179

89. Valvassori SS, Elias G, de Souza B, Petronilho F, Dal-Pizzol F, Kapczinski F, et al. Effects of cannabidiol on amphetamine-induced oxidative stress generation in an animal model of mania. J Psychopharmacol. (2011) 25:27480. doi: 10.1177/0269881109106925

90. Réus GZ, Stringari RB, Ribeiro KF, Luft T, Abelaira HM, Fries GR, et al. Administration of cannabidiol and imipramine induces antidepressant-like effects in the forced swimming test and increases brain-derived neurotrophic factor levels in the rat amygdala. Acta Neuropsychiatr. (2011) 23:241-8. doi: 10.1111/j.1601-5215.2011.00579.x

91. Valvassori SS, Bavaresco DV, Scaini G, Varela RB, Streck EL, Chagas $\mathrm{MH}$, et al. Acute and chronic administration of cannabidiol increases mitochondrial complex and creatine kinase activity in the rat brain. Rev Bras Psiquiatr. (2013) 35:380-6. doi: 10.1590/1516-4446-2012-0886

92. Cassol-Jr OJ, Comim CM, Silva BR, Hermani FV, Constantino LS, Felisberto F, et al. Treatment with cannabidiol reverses oxidative stress parameters, cognitive impairment and mortality in rats submitted to sepsis by cecal ligation and puncture. Brain Res. (2010) 1348:128-38. doi: 10.1016/j.brainres.2010.06.023

93. Barichello T, Ceretta RA, Generoso JS, Moreira AP, Simões LR, Comim CM, et al. Cannabidiol reduces host immune response and prevents cognitive impairments in Wistar rats submitted to pneumococcal meningitis. Eur J Pharmacol. (2012) 697:158-64. doi: 10.1016/j.ejphar.2012.09.053

94. Fagherazzi EV, Garcia VA, Maurmann N, Bervanger T, Halmenschlager LH, Busato SB, et al. Memory-rescuing effects of cannabidiol in an animal model of cognitive impairment relevant to neurodegenerative disorders. Psychopharmacology (2012) 219:1133-40. doi: 10.1007/s00213-011-2449-3

95. da Silva VK, de Freitas BS, da Silva Dornelles A, Nery LR, Falavigna L, et al. Cannabidiol normalizes caspase 3, synaptophysin, and mitochondrial fission protein DNM1L expression levels in rats with brain iron overload: implications for neuroprotection. Mol Neurobiol. (2014) 49:222-33. doi: $10.1007 /$ s12035-013-8514-7

96. Kays JL, Hurley RA, Taber KH. The dynamic brain: neuroplasticity and mental health. J Neuropsychiatry Clin Neurosci (2012) 24:118-24. doi: 10.1176/appi.neuropsych.12050109

97. Pallanti S. ICD and DSM: neuroplasticity and staging are still missing. CNS Spectr. (2016) 21:276-8. doi: 10.1017/S1092852916000146

98. Dhikav V, Anand KS. Is hippocampal atrophy a future drug target? Med Hypotheses (2007) 68:1300-6. doi: 10.1016/j.mehy.2006.09.040

99. Bessa JM, Ferreira D, Melo I, Marques F, Cerqueira JJ, Palha JA, et al. The mood-improving actions of antidepressants do not depend on neurogenesis but are associated with neuronal remodeling. Mol Psychiatry (2009) 14:76473. doi: $10.1038 / \mathrm{mp} .2008 .119$

100. Deng W, Aimone JB, Gage FH. New neurons and new memories: how does adult hippocampal neurogenesis affect learning and memory? Nat Ver Neurosci. (2010) 11:339-50. doi: 10.1038/nrn2822

101. Kempermann G. The neurogenic reserve hypothesis: what is adult hippocampal neurogenesis good for? Trends Neurosci. (2008) 31:163-9. doi: 10.1016/j.tins.2008.01.002

102. Reif A, Fritzen S, Finger M, Strobel A, Lauer M, Schmitt A, et al. Neural stem cell proliferation is decreased in schizophrenia, but not in depression. $\mathrm{Mol}$ Psychiatry (2006) 11:514-22. doi: 10.1038/sj.mp.4001791

103. Lucassen PJ, Meerlo P, Naylor AS, van Dam AM, Dayer AG, Fuchs E, et al. Regulation of adult neurogenesis by stress, sleep disruption, exercise and inflammation: Implications for depression and antidepressant action. Eur Neuropsychopharmacol. (2010) 20:1-17. doi: 10.1016/j.euroneuro.2009.08.003

104. Wolf SA, Bick-SanderA, Fabel K, Leal-Galicia P, Tauber S, RamirezRodriguez G, et al. Cannabinoid receptor CB1 mediates baseline and activityinduced survival of new neurons in adult hippocampal neurogenesis. Cell Commun Signal. (2010) 8:12. doi: 10.1186/1478-811X-8-12

105. Esposito G, Scuderi C, Valenza M, Togna GI, Latina V, de Filippis D, et al. Cannabidiol reduces $\mathrm{A} \beta$-induced neuroinflammation and promotes hippocampal neurogenesis through PPAR $\gamma$ involvement. PLoS ONE (2011) 6:e28668. doi: 10.1371/journal.pone.0028668

106. Schiavon AP, Bonato JM, Milani H, Guimarães FS, Weffort de Oliveira RM. Influence of single and repeated cannabidiol administration on emotional behavior and markers of cell proliferation and neurogenesis in nonstressed mice. Prog Neuropsychopharmacol Biol Psychiatry (2016) 64:27-34. doi: 10.1016/j.pnpbp.2015.06.017

107. Demirakca T, Sartorius A, Ende G, Meyer N, Welzel H, Skopp G, et al. Diminished gray matter in the hippocampus of cannabis users: possible protective effects of cannabidiol. Drug Alcohol Depend. (2011) 114:242-5. doi: 10.1016/j.drugalcdep.2010.09.020

108. Santos NA, Martins NM, Sisti FM, Fernandes LS, Ferreira RS, Queiroz $\mathrm{RH}$, et al. The neuroprotection of cannabidiol against MPP?-induced toxicity in PC12 cells involves trkA receptors, upregulation of axonal and synaptic proteins, neuritogenesis, and might be relevant to Parkinson's disease. Toxicol in vitro (2015) 30:231-40. doi: 10.1016/j.tiv.2015. 11.004

109. Solinas M, Massi P, Cinquina V, Valenti M, Bolognini D, Gariboldi M, et al. Cannabidiol, a non-psychoactive cannabinoid compound, inhibits proliferation and invasion in U87-MG and T98G glioma cells through a multitarget effect. PLoS ONE (2013) 8:e76918. doi: 10.1371/journal.pone.0076918.

110. McAllister SD, Murase R, Christian RT, Lau D, Zielinski AJ, Allison J, et al. Pathways mediating the effects of cannabidiol on the reduction of breast cancer cell proliferation, invasion, and metastasis. Breast Cancer Res Treat. (2011) 129:37-47. doi: 10.1007/s10549-010-1177-4

111. ElBatsh MM, Assareh N, Marsden CA, Kendall DA. Anxiogenic-like effects of chronic cannabidiol administration in rats. Psychopharmacology (2012) 221:239-47. doi: 10.1007/s00213-011-2566-Z

112. Campos AC, Fogaça MV, Scarante FF, Joca SRL, Sales AJ, Gomes FV. Plastic and neuroprotective mechanisms involved in the therapeutic effects of cannabidiol in psychiatric disorders. Front Pharmacol. (2017) 8:269. doi: 10.3389/fphar.2017.00269

113. Hampson AJ, Grimaldi M, Axelrod J, Wink D. Cannabidiol and (-)Delta9tetrahydrocannabinol are neuroprotective antioxidants. Proc Natl Acad Sci USA. (1998) 95:8268-73. doi: 10.1073/pnas.95.14.8268

114. Esposito G, De Filippis D, Maiuri MC, De Stefano D, Carnuccio $\mathrm{R}$, Iuvone $\mathrm{T}$. Cannabidiol inhibits inducible nitric oxide synthase protein expression and nitric oxide production in beta-amyloid stimulated PC12 neurons through p38 MAP kinase and NF-kappaB involvement. Neurosci Lett. (2006) 399:91-5. doi: 10.1016/j.neulet.2006. 01.047

115. Janefjord E, Mååg JL, Harvey BS, Smid SD. Cannabinoid effects on $\beta$ amyloid fibril and aggregate formation, neuronal and microglialactivated neurotoxicity in vitro. Cell Mol Neurobiol. (2014) 34:31-42. doi: $10.1007 /$ s10571-013-9984-x 
116. Harvey BS, Ohlsson KS, Mååg JL, Musgrave IF, Smid SD. Contrasting protective effects of cannabinoids against oxidative stress and amyloid$\beta$ evoked neurotoxicity in vitro. Neurotoxicology (2012) 33:138-46. doi: 10.1016/j.neuro.2011.12.015

117. Esposito G, Scuderi C, Savani L, Steardo Jr D, De Filippis P, Cottone T, et al. Cannabidiol in vivo blunts beta-amyloid induced neuroinflammation by suppressing IL-1beta and iNOS expression. Br J Pharmacol. (2007) 151:1272-9. doi: 10.1038/sj.bjp.0707337

118. Sagredo O, Ramos JA, Decio A, Mechoulam R, Fernández-Ruiz J. Cannabidiol reduced the striatal atrophy caused 3-nitropropionic acid in vivo by mechanisms independent of the activation of cannabinoid, vanilloid TRPV1 and adenosine A2A receptors. Eur J Neurosci. (2007) 26:843-51. doi: 10.1111/j.1460-9568.2007.05717.x

119. Garcia-Arencibia M, Gonzalez S, de Lago E, Ramos JA, Mechoulam R, Fernandez-Ruiz J. Evaluation of the neuroprotective effect of cannabinoids in a rat model of Parkinson's disease: importance of antioxidant and cannabinoid receptor-independent properties. Brain Res. (2007) 1134:16270. doi: 10.1016/j.brainres.2006.11.063

120. Sagredo O, Pazos MR, Satta V, Ramos JA, Pertwee RG, FernándezRuiz J. Neuroprotective effects of phytocannabinoid-based medicines in experimental models of Huntington's disease. J Neurosci Res. (2011) 89:150918. doi: $10.1002 /$ jnr.22682

121. Mecha M, Torrao AS, Mestre L, Carrillo-Salinas FJ, Mechoulam R, Guaza C. Cannabidiol protects oligodendrocyte progenitor cells from inflammationinduced apoptosis by attenuating endoplasmic reticulum stress. Cell Death Dis. (2012) 3:e331. doi: 10.1038/cddis.2012.71

122. Rajesh M, Mukhopadhyay P, Bátkai S, Haskó G, Liaudet L, Drel VR, et al (2007). Cannabidiol attenuates high glucose-induced endothelial cell inflammatory response and barrier disruption. Am J Physiol Heart Circ Physiol. 293:H610-9. doi: 10.1152/ajpheart.00236.2007

123. Castillo A, Tolón MR, Fernández-Ruiz J, Romero J, Martinez-Orgado J. The neuroprotective effect of cannabidiol in an in vitro model of newborn hypoxic-ischemic brain damage in mice is mediated by $\mathrm{CB}(2)$ and adenosine receptors. Neurobiol Dis. (2010) 37:434-40. doi: 10.1016/j.nbd.2009. 10.023

124. Pazos MR, Mohammed N, Lafuente H, Santos M, MartínezPinilla E, Moreno E, et al. Mechanisms of cannabidiol neuroprotection in hypoxic-ischemic newborn pigs: role of 5HT(1A) and CB2 receptors. Neuropharmacology (2013) 71:282-91. doi: 10.1016/j.neuropharm.2013.03.027

125. Mori MA, Meyer E, Soares LM, Milani H, Guimarães FS, de Oliveira RM. Cannabidiol reduces neuroinflammation and promotes neuroplasticity and functional recovery after brain ischemia. Prog Neuropsychopharmacol Biol Psychiatry (2017) 75:94-105 doi: 10.1016/j.pnpbp.2016.11.005

126. Sun $\mathrm{S}, \mathrm{Hu} \mathrm{F}, \mathrm{Wu}$ J, Zhang S. Cannabidiol attenuates OGD/R-induced damage by enhancing mitochondrial bioenergetics and modulating glucose metabolism via pentose-phosphate pathway in hippocampal neurons. Redox Biol. (2017) 11:577-85. doi: 10.1016/j.redox.2016.12.029

127. Magen I, Avraham Y, Ackerman Z, Vorobiev L, Mechoulam R, Berry EM. Cannabidiol ameliorates cognitive and motor impairments in bileduct ligated mice via 5-HT1A receptor activation. Br J Pharmacol. (2010) 159:950-7. doi: 10.1111/j.1476-5381.2009.00589.x

128. Avraham Y, Grigoriadis N, Poutahidis T, Vorobiev L, Magen I, Ilan Y, et al. Cannabidiol improves brain and liver function in a fulminant hepatic failureinduced model of hepatic encephalopathy in mice. Br J Pharmacol. (2011) 162:1650-8. doi: 10.1111/j.1476-5381.2010.01179.x

129. Lastres-Becker I, Molina-Holgado F, Ramos JA, Mechoulam R, FernándezRuiz J. Cannabinoids provide neuroprotection against 6-hydroxydopamine toxicity in vivo and in vitro: relevance to Parkinson's disease. Neurobiol Dis. (2005) 19:96-107. doi: 10.1016/j.nbd.2004.11.009

130. Jia J, Le W. Molecular network of neuronal autophagy in the pathophysiology and treatment of depression. Neurosci Bull. (2015) 31:427-34. doi: 10.1007/s12264-015-1548-2

131. Hosseinzadeh M, Nikseresht S, Khodagholi F, Naderi N, Maghsoudi N. Cannabidiol post-treatment alleviates rat epileptic-related behaviors and activates hippocampal cell autophagy pathway along with antioxidant defense in chronic phase of pilocarpine-induced seizure. J Mol Neurosci. (2016) 58:432-40. doi: 10.1007/s12031-015-0703-6
132. Carlini EA, Leite JR, Tanhauser M, Berardi AC. Cannabidiol and Cannabis sativa extract protect mice and rats against convulsive agents. J Pharm Pharmacol. (1973) 25:664-5. doi: 10.1111/j.2042-7158.1973.tb10660.x

133. Izquierdo I, Orsingher OA, Berardi AC. Effect of cannabidiol and other Cannabis sativa compounds on hippocampal seizures discharges. Psychopharmacologia (1973) 28:95-102. doi: 10.1007/BF00413961

134. Cunha JM, Carlini EA, Pereira AE, Ramos OL, Pimentel G, Gagliardi R, et al. Chronic administration of cannabidiol to healthy volunteers and epileptic patients. Pharmacology (1980) 21:175-85. doi: 10.1159/000137430

135. Do Val-da Silva RA, Peixoto-Santos JE, Kandratavicius L, De Ross JB, Esteves I, De Martinis BS, et al. Protective effects of Cannabidiol against seizures and neuronal death in a rat model of mesial temporal lobe epilepsy. Front Pharmacol. (2017) 8:131. doi: 10.3389/fphar.2017.00131

136. Crippa JA, Crippa AC, Hallak JE, Martín-Santos R, Zuardi AW. $\Delta 9$-THC intoxication by cannabidiol-enriched cannabis extract in two children with refractory epilepsy: full remission after switching to purified cannabidiol. Front Pharmacol. (2016) 7:359. doi: 10.3389/fphar.2016.00359

137. Devinsky O, Marsh E, Friedman D, Thiele E, Laux L, Sullivan J, et al. Cannabidiol in patients with treatment-resistant epilepsy: an open-label interventional trial. Lancet Neurol. (2016) 15:270-8. doi: 10.1016/S1474-4422(15)00379-8

138. Devinsky O, Cross JH, Laux L, Marsh E, Miller I, Nabbout R, et al. Trial of cannabidiol for drug-resistant seizures in the dravet syndrome. $\mathrm{N} \mathrm{Engl} \mathrm{J} \mathrm{Med.}$ (2017) 376:2011-20. doi: 10.1056/NEJMoa1611618

139. Devinsky O, Patel AD, Cross JH, Villanueva V, Wirrell EC, Privitera M, et al. Effect of cannabidiol on drop seizures in the lennox-gastaut syndrome. $N$ Engl J Med. (2018) 378:1888-97. doi: 10.1056/NEJMoa1714631

140. Thiele EA, Marsh ED, French JA, Mazurkiewicz-Beldzinska M, Benbadis SR, Joshi C, et al. (2018). Cannabidiol in patients with seizures associated with Lennox-Gastaut syndrome (GWPCARE4): a randomised, double-blind, placebo-controlled phase 3 trial. Lancet 391:1085-96. doi: 10.1016/S0140-6736(18)30136-3

141. ClinicalTrials.gov Identifier NCT02783092. A Double Blind, Randomized Placebo-controlled Trial to Evaluate Efficacy and Safety of Cannabidiol as an add-on Therapy for Treatment in Refractory Epileptic Crisis in Children and Adolescents.

142. Chagas MH, Zuardi AW, Tumas V, Pena-Pereira MA, Sobreira ET, Bergamaschi MM, et al. Effects of cannabidiol in the treatment of patients with Parkinson's disease: an exploratory double-blind trial. $J$ Psychopharmacol. (2014) 28:1088-98. doi: 10.1177/0269881114550355

143. Crippa JA, Derenusson GN, Chagas MH, Atakan Z, Martín-Santos R, Zuardi AW, et al. Pharmacological interventions in the treatment of the acute effects of cannabis: a systematic review of literature. Harm Reduct J. (2012) 9:7. doi: 10.1186/1477-7517-9-7

144. Crippa JA, Hallak JE, Machado-de-Sousa JP, Queiroz RH, Bergamaschi M, Chagas MH, et al. (2013). Cannabidiol for the treatment of cannabis withdrawal syndrome: a case report. J Clin Pharm Ther. 38:162-4. doi: $10.1111 /$ jcpt. 12018

145. Gobira PH, Vilela LR, Gonçalves BD, Santos RP, de Oliveira AC, Vieira LB, et al. Cannabidiol, a Cannabis sativa constituent, inhibits cocaine-induced seizures in mice: Possible role of the mTOR pathway and reduction in glutamate release. Neurotoxicology (2015) 50:116-21. doi: 10.1016/j.neuro.2015.08.007

146. Zuardi A, Crippa J, Dursun S, Morais S, Vilela J, Sanches R, et al. Cannabidiol was ineffective for manic episode of bipolar affective disorder. J Psychopharmacol. (2010) 24:135-7. doi: 10.1177/02698811080 96521

147. Hallak JE, Crippa JA, Quevedo J, Roesler R, Schröder N, Nardi AE, et al. National Science and Technology Institute for Translational Medicine (INCT-TM): advancing the field of translational medicine and mental health. Rev Bras Psiquiatr. (2010) 32:83-90. doi: 10.1590/S1516-444620100001 00016

148. Schönhofen P, de Medeiros LM, Bristot IJ, Lopes FM, De Bastiani MA, Kapczinski F, et al. Cannabidiol exposure during neuronal differentiation sensitizes cells against redox-active neurotoxins. Mol Neurobiol. (2015) 52:26-37. doi: 10.1007/s12035-014-8843-1

149. Vuolo F, Petronilho F, Sonai B, Ritter C, Hallak JE, Zuardi AW, et al. Evaluation of serum cytokines levels and the role of cannabidiol treatment 
in animal model of asthma. Mediators Inflamm. (2015) 2015:538670. doi: $10.1155 / 2015 / 538670$

150. Ribeiro A, Ferraz-de-Paula V, Pinheiro ML, Vitoretti LB, Mariano-Souza DP, Quinteiro-Filho WM, et al. Cannabidiol, a non-psychotropic plant-derived cannabinoid, decreases inflammation in a murine model of acute lung injury: role for the adenosine A(2A) receptor. Eur J Pharmacol. (2012) 678:78-85. doi: 10.1016/j.ejphar.2011.12.043

151. Chagas MH, Crippa JA, Zuardi AW, Hallak JE, Machado-de-Sousa JP, Hirotsu C, et al. Effects of acute systemic administration of cannabidiol on sleep-wake cycle in rats. J Psychopharmacol. (2013) 27:312-6. doi: $10.1177 / 0269881112474524$

152. Callejas GH, Figueira RL, Gonçalves FLL, Volpe FAP, Zuardi AW, Crippa JA, et al. Maternal administration of cannabidiol promotes aN antiinflammatory effect on the intestinal wall in a gastroschisis rat model. Braz J Med Biol Res. (2018)51:e7132. doi: 10.1590/1414-431x20177132

153. Peres FF, Lima AC, Hallak JEC, Crippa JA, Silva RH, Abílio VC. Cannabidiol as a promising strategy to treat and prevent movement disorders? Front Pharmacol. (2018) 9:482. doi: 10.3389/fphar.2018.00482

154. Nazario, L. R., Antonioli, R., Jr, Capiotti, K. M., Hallak, J. E., Zuardi, A. W., et al. Caffeine protects against memory loss induced by high and nonanxiolytic dose of cannabidiol in adult zebrafish (Danio rerio). Pharmacol Biochem Behav. (2015) 135:210-6. doi: 10.1016/j.pbb.2015.06.008

155. Levin R, Peres FF, Almeida V, Calzavara MB, Zuardi AW, Hallak JE, et al. Effects of cannabinoid drugs on the deficit of prepulse inhibition of startle in an animal model of schizophrenia: the SHR strain. Front Pharmacol. (2014) 5:10. doi: 10.3389/fphar.2014.00010

156. Twardowschy A, Castiblanco-Urbina MA, Uribe-Mariño A, Biagioni AF, Salgado-Rohner CJ, Crippa JA, et al. The role of 5-HT1A receptors in the anti-aversive effects of cannabidiol on panic attack-like behaviors evoked in the presence of the wild snake Epicrates cenchria crassus (Reptilia, Boidae). J Psychopharmacol. (2013) 27:1149-59. doi: 10.1177/0269881113493363

157. Almeida V, Levin R, Peres FF, Niigaki ST, Calzavara MB, Zuardi AW, et al. Cannabidiol exhibits anxiolytic but not antipsychotic property evaluated in the social interaction test. Prog Neuropsychopharmacol Biol Psychiatry (2013) 41:30-5. doi: 10.1016/j.pnpbp.2012.10.024

158. Ribeiro A, Almeida VI, Costola-de-Souza C, Ferraz-de-Paula V, Pinheiro ML, Vitoretti LB, et al. Cannabidiol improves lung function and inflammation in mice submitted to LPS-induced acute lung injury. Immunopharmacol Immunotoxicol. (2015) 37:35-41. doi: 10.3109/08923973.2014.976794

159. Breuer A, Haj CG, Fogaça MV, Gomes FV, Silva NR, Pedrazzi JF, et al. Fluorinated cannabidiol derivatives: enhancement of activity in mice models predictive of anxiolytic, antidepressant and antipsychotic effects. PLOS ONE (2016) 11:e0158779. doi: 10.1371/journal.pone.0158779

160. Silva NR, Gomes FV, Fonseca MD, Mechoulam R, Breuer A, Cunha TM, et al. Antinociceptive effects of HUF-101, a fluorinated cannabidiol derivative. Prog Neuropsychopharmacol Biol Psychiatry (2017) 79:369-77. doi: 10.1016/j.pnpbp.2017.07.012

161. Mead A. The legal status of cannabis (marijuana) and cannabidiol (CBD) under U.S. law. Epilepsy Behav. (2017) 70(Pt B):288-91. doi: 10.1016/j.yebeh.2016.11.021

Conflict of Interest Statement: AZ, FG, and JC are co-inventors (Mechoulam R, JC, FG, AZ, JH, Breuer A) of the patent "Fluorinated CBD compounds, compositions and uses thereof. Pub. No.: WO/2014/108899. International Application No.: PCT/IL2014/050023” Def. US no. Reg. 62193296; 29/07/2015; INPI on 19/08/2015 (BR1120150164927). The University of São Paulo has licensed the patent to Phytecs Pharm (USP Resolution No. 15.1.130002.1.1). The University of São Paulo has an agreement with Prati-Donaduzzi (Toledo, Brazil) to "develop a pharmaceutical product containing synthetic cannabidiol and prove its safety and therapeutic efficacy in the treatment of epilepsy, schizophrenia, Parkinson's disease, and anxiety disorders." JC has received travel support from and is medical advisors of BSPG-Pharm.

The remaining author declares that the research was conducted in the absence of any commercial or financial relationships that could be construed as a potential conflict of interest.

Copyright $\odot 2018$ Crippa, Guimarães, Campos and Zuardi. This is an open-access article distributed under the terms of the Creative Commons Attribution License (CC $B Y)$. The use, distribution or reproduction in other forums is permitted, provided the original author(s) and the copyright owner(s) are credited and that the original publication in this journal is cited, in accordance with accepted academic practice. No use, distribution or reproduction is permitted which does not comply with these terms. 